\title{
Floristic composition and comparison of middle Eocene to late Eocene and Oligocene floras in North America
}

\author{
Melanie L. DeVore \& Kathleen B. PigG
}

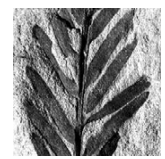

\begin{abstract}
In comparison to the early and middle Eocene, the late Eocene and particularly the Oligocene floral record is sparse in North America. Changing tectonic, environmental and climatic conditions during these times resulted in the development of fewer depositional systems favorable for fossil preservation. Floras are known from the Southeast, the Pacific Northwest and the Rocky Mountains. Each area has a distinct geological history that shaped both the vegetation adjacent to sites of deposition as well as the depositional environments themselves. The floristic change from middle to late Eocene, and then to Oligocene reflects a changing paleoclimate from the thermal maximum to cooler and drier conditions in the late Paleogene. In the present paper, major middle, and then late Eocene and finally Oligocene floras of North America are summarized, with an emphasis on their regional geology, depositional setting, paleoclimate and significant floral elements. The North American occurrences of coryphoid palms ( $\mathrm{Sabal}$ ) and cycads are reviewed in relationship to their biogeographic history. Finally, we suggest several directions for future research that will further illuminate the floristic changes from middle, to late Eocene and Oligocene that occurred in North America. - Key words: Claiborne, Eocene/Oligocene transition, Florissant, Okanogan Highlands, Tertiary floras.
\end{abstract}

DeVore, M.L. \&. PigG, K.B. 2010. Floristic composition and comparison of middle Eocene to late Eocene and Oligocene floras in North America. Bulletin of Geosciences 85(1), 111-134 (1 figure, 2 tables). Czech Geological Survey, Prague. ISSN 1214-1119. Manuscript received April 7, 2009; accepted in revised form October 5, 2009; published online January 8, 2010; issued xxxx xx, 2010.

Melanie L. DeVore (corresponding author), Georgia College \& State University, 135 Herty Hall, Milledgeville, GA 31062-0001, USA; melanie.devore@ gcsu.edu・Kathleen B. Pigg, School of Life Sciences, Arizona State University, PO Box 874501, Tempe AZ 85287-4501 USA; kpigg@asu.edu

Assemblages of plant-bearing fossiliferous sedimentary rocks of the late Eocene and especially Oligocene ages are rare in North America (Wing 1987). There are several reasons why this is so. First, the extensive Paleogene fluvial plain covering the region once occupied by the Cretaceous Intercontinental Seaway became diminished, limiting the areas with the appropriate conditions necessary for plant preservation. Secondly, climate became drier, leading to fewer environments of deposition available for preserving megafossils. Thirdly, the ash-producing volcanism responsible for blocking drainage systems in the western Rocky Mountains to create depositional basins decreased during the Oligocene (Graham 1999). Thus the combination of changing geomorphology, drying climate and less volcanic activity all contributed to the decreased number and extent of fossil plant beds of this age. As a result, the transition from the robust fossil records of the early and middle Eocene into the late Eocene and Oligocene is only broadly understood.

Despite the limited late Eocene and Oligocene plant bed exposures in North America, this is an important time period to study for several reasons. First, these floras mark a major shift in climate from the warmer and more humid middle
Eocene toward the cooler and drier conditions that continue to the present day. Floral response to climate change has been studied by both the Nearest Living Relative method (NLR) and leaf physiognomy. The NLR uses the distribution of closely related living plants to infer climate in fossil floras (e.g., Axelrod 1957, 1966a). This method is valuable, however fossil forms may not have occupied identical niches or had equal physiological tolerances as their current relatives. Leaf physiognomic methods such as Leaf Margin Analysis (LMA), Leaf Area (LA) and Climate-Leaf Analysis Multivariate Program (CLAMP) are based on assemblages of extant leaves characterized by characters of size and shape correlated to their occurrence in modern environments. These taxon-free approaches provide a means independent of systematic affinities for estimating climate (Wolfe 1987, Graham 1999). Easily quantifiable leaf physiognomy techniques have become a powerful tool for providing numerical data that can be compared readily with other proxies, such as carbon isotopes. These two types of methods often are used in combination to establish estimates of paleoclimate and paleoelevation parameters (e.g., Greenwood et al. 2005). 
A second major area of interest is the origin and diversification of major taxonomic groups. As taxon-free methods have become de rigueur for climate reconstruction, traditional systematic studies of fossil plants have shifted toward novel applications that relate to molecular phylogenetics and biogeography (Manchester 1999, Manos \& Stanford 2001, Tiffney \& Manchester 2001, Manos et al. 2007, Manchester et al. 2009). Fossil occurrences act as an independent proxies for dating nodes of divergence for molecular and/or combined data sets. They also provide a means for examining character evolution, and broad responses of lineages to environmental change, as well as demonstrating past distributions. The middle to late Eocene and then Oligocene floras mark important chapters in the evolutionary and biogeographic history of major plant groups as they adapt, diversify, and wax or wane in the fossil record.

In this contribution the major floras of middle to late Eocene and Oligocene ages in North America are reviewed, with a brief description of the geological setting, depositional environment, and paleoclimate of each, followed by a description of significant floral elements (Table 1). This study presents more detail about several floras that to date have not been comprehensively summarized. Fossil occurrences of cycads and coryphoid palms are reviewed for North America in relationship to their biogeographic history. Lastly, directions for future research are suggested that will further illuminate an understanding of the late Eocene and Oligocene floras of North America.

\section{Overview of the floras}

\section{Middle Eocene to Early Oligocene in the Southeast Mississippi Embayment}

One of the best glimpses of the late Eocene and Oligocene floras comes from southeastern North America in the region of the Mississippian Embayment. These floras were initially surveyed by Berry $(1916,1922,1924,1925,1930$, 1941) who, over the course of 25 years, described more than 340 species of Eocene and Oligocene fossil plants, many from this floristic region (Pigg \& DeVore 2007). Many of Berry's identifications have been reinterpreted, so subsequent papers should be consulted. A sustained effort in studying Mississippian Embayment floras from the middle Eocene Claiborne Formation commenced with Dilcher's (1963b, 1965) work on fossil leaves with epiphyllous fungi. Detailed taxonomic studies followed, based on the excellent cuticular preservation of fossil leaves and fruits from the Claiborne, leading to the eventual description of over 30 megafossil genera in approximately 15 families (Table 2).
Determination of precise ages and depositional environments within the Claiborne Formation is limited because stratigraphic units are difficult to correlate. The most extensively studied plants of the Claiborne occur in localized clay pits (e.g., Puryear, Warman, Lamkin). These outcrops are small, discontinuous units not found in conjunction with marine deposits or other biostratigraphically informative sediments. In contrast to localities in the West that are commonly associated with intense orogenic activity during the Cenozoic, the Mississippian Embayment is on the passive margin of the North American plate and typically lacks datable ashes and other igneous units. Since radiometric dating is not available, floras in the region are correlated primarily by pollen zonation (Elsik \& Dilcher 1974, Potter \& Dilcher 1980, Table 1).

The depositional environments of the Claiborne Formation have been interpreted in several ways. Originally, Berry (1916) considered the Claiborne to be the result of a series of fluvial and lacustrine deposits in back-beach areas of the Gulf of Mexico. Dilcher (1971) attributed the clay lenses of Henry and Weakley Counties of Tennessee to deposits in abandoned river channels of oxbow lakes occupying a low-lying floodplain. In one study Moore et al. (2001) suggested that the section exposed at the Wilbanks Clay Pit in western Tennessee may have been deposited in one to several seasons.

Multiple overlapping clay lenses with truncated margins, cut-and-fills, and cross-bedded sandstones containing clay rip-ups were found in northeastern outcrops of the Claiborne. Some of these plant-bearing clays are interpreted as being deposited within a braided stream system (Moore et al. 2003). Based on the three-dimensional structure of several clay lenses characterized by distinct lower contacts and fine laminated bedding, Moore et al. (2003) later proposed that rates of infilling probably occurred in these deposits over a 1,000-2,000 year period. Future studies, particularly within the context of basin analysis, may help to clarify the apparent contrasting modes of deposition within the Claiborne.

The Mean Annual Temperature (MAT) for Claiborne has been estimated variously as between $20-28{ }^{\circ} \mathrm{C}$ or 22-30 ${ }^{\circ} \mathrm{C}$ (Graham 1999). Dilcher (1973) suggested that the climate was similar to coastal Louisiana $\left(21^{\circ} \mathrm{C}\right)$ or to southern peninsular Florida $\left(24{ }^{\circ} \mathrm{C}\right)$. These estimates, with MAT above $20{ }^{\circ} \mathrm{C}$, indicate a megathermal flora (Wolfe 1987). The Claiborne is characterized as a dry tropical forest (Wolfe 1978) with the dominant plant groups being lauraceous leaves, castaneoid and transitional oaks and legumes representing all three major groups (Dilcher 1963a; Crepet \& Dilcher 1977; Crepet \& Daghlian 1980; Herendeen \& Dilcher 1990a, b, c). Very large monocot leaves (up to $75 \mathrm{~cm}$ wide) with entire margins assigned to Araceae occur (Dilcher \& Daghlian 1977), as do Juglandaceae of subfamily Engelhardiodeae, 
today a completely Asian clade (Dilcher \& Manchester 1986, Manos \& Stanford 2001, Manos et al. 2007). Other families reported from the Claiborne Formation include Eucommiaceae, Euphorbiaceae, Oleaceae, Theaceae, Rhamnaceae and Ulmaceae (Table 2). Palms are common and almost all are coryphoid. Interestingly, the only aquatic plant found in the Claiborne Formation is the floating Ceratophyllum (Herendeen et al. 1990). Unlike many other middle Eocene floras, Betulaceae and taxoidaceous conifers are rare if at all present, and the only published conifer remains have been attributed to Podocarpus (Dilcher 1969).

To the southwest of the Claiborne, the Catahoula Formation of east Texas is a rare record of early Oligocene plant megafossils in the Mississippian Embayment. Along with the Claiborne, the Catahoula provides some invaluable insights regarding the biogeography of the Mississippian Embayment. Berry (1916) first reported fossil plant remains near Huntsville, Texas, but the leaf material was in a rather coarse sandstone bed. Additional fossils in a finer matrix that preserved excellent plant cuticle were recovered during the 1970s-80s, when the Riverside Crushed Stone Company was actively quarrying the region.

In the 1990's when the quarry was transformed into a lake and became used as a site for certifying scuba divers, most of the significant fossil plant beds became inaccessible.

Galloway (1977) believed that two depositional systems are represented in east Texas: the Gueydan bedload fluvial system of the Rio Grande Embayment and the Chita-Corrigan mixed load fluvial system of the Houston Embayment. Freile et al. (2003) reported the presence of glauconite in the Huntsville section and interpreted this occurence to indicate shelf (60-550 m) or shallow marine environments and/or a transgressive episode. The lithology of samples indicates a multiple provenance rock that includes volcanic grains, sub-rounded chert and quartz grains, while other quartz clearly is metamorphic in origin.

The Catahoula flora is rich in legumes, transitional oaks and other Fagaceae, palms, juglandaceous and possibly euphorboid fruits (Daghlian et al. 1980, Herendeen \& Dilcher 1990a, Herendeen et al. 1992, Manchester \& Dilcher 2007). The site is especially important in documenting the early evolution of Fagaceae with pollen-bearing flowers of intermediate and trigonobalanoid oaks occuring side-by-side with modern-appearing, apparently black oak leaves and white oak acorns (Daghlian \& Crepet 1983; Crepet \& Nixon 1989a, b). A spiny cupule (the "frilly fruit") with possible affinities to Fagaceae, also known from the Claiborne has been reported (Pigg et al. 2001a), and Taxodium seed cones and leaves have been identified (DeVore, personal observation).

\section{The Middle Eocene in the Rocky Mountains - The Green River flora}

In the West, the Eocene to Oligocene is well represented in the Rocky Mountains, particularly in Colorado, Utah and Wyoming. During the early and middle Eocene in this area significant floras were preserved in three basins occupied by extensive, shallow lakes: Uinta Basin (Lake Uinta), Green River Basin (Lake Gosiute) and Fossil Basin (Fossil Lake; Roehler 1993, Graham 1999). The flora of the Green River Formation, primarily exposed in the Green River Basin was treated by R. Brown (1934) and MacGinitie (1969).

The Green River Formation is one of the most diverse lacustrine systems in the world and contains several tuff beds that provide a means of dating and determining rate of sediment accumulation and timing of faunal and floristic changes (G. Smith et al. 1998). A broad range of facies are represented and these have been described and subdivided into facies associations as (1) evaporative, (2) fluctuating profundal, and (3) fluvio-lacustrine (Carrol \& Bohacs 1999). A fluvial-lacustrine facies association is represented by the Luman Tongue. This horizon contains defining mudstone, sandstone, coal and coquina lithologies in conjunction with root casts, coarse lamination and fluvial channels. Typical parasequences grade from calcareous mudstones and silstones into shelly coquinas, deltaic sands and thin coals. All of these features are definitive of a hydrologically open lake (Horsfield et al. 1994, Carrol \& Bohacs 1999). The Luman Tongue is fossiliferous, and contains more of a fauna and less of a flora than the slightly younger Parachute Member, which is widely known for its economically valuable oil shale deposits and rich fossil records of insects and plants (McGinitie 1969). Like the Luman Tongue, the Parachute Member represents a hydrologically open lake stage of Lake Uinta (MacGinitie 1969). Outcrops of the Parachute Member are best exposed in the Piceance Creek Basin, near Douglas Pass, Colorado and in the Uinta Basin near Bonanza, Utah. Radiometric ages from ${ }^{40} \mathrm{Ar} /{ }^{39} \mathrm{Ar}$ laser fusion of biotite and hornblende crystals date the fossiliferous horizon above the Mahogany marker bed at $48.13 \pm 0.71$ and 48.22 \pm 0.71 (Malchus et al. 2002, Boucher et al. 2003).

The Green River flora is the Western assemblage that bears the closest resemblance to the Claiborne, and accordingly has been studied extensively by Dilcher and colleagues. Floristic similarities with the Claiborne include coryphoid palms, legumes, Ceratophyllum Engelhardia, and Eucommia (Herendeen et al. 1990; Call \& Dilcher 1994, 1997). The most abundant Green River megafossil elements in addition to palm leaves are the climbing fern Lygodium (Manchester \& Zavada 1987) and Sapindus. Ptelea (Call \& Dilcher 1995), Typha, Musophyllum, and Zingiberopsis are also common, and 
Table 1. Comparison of floras discussed in text. Abbreviations: e - early, m - middle, 1 - late, Fm - Formation, High - Highlands, Is - Island, Mem Member, Mtn - Mountain, ss - sandstone; lo - lower, mid - middle, up - upper; BC - British Columbia, CO - Colorado, ID - Idaho, KY - Kentucky, MT - Montana, TN - Tennessee, UT - Utah, WA - Washington, WY - Wyoming; * - interconnected organs.

\begin{tabular}{|c|c|c|c|c|c|c|}
\hline $\begin{array}{l}\text { Flora } \\
\text { Main references }\end{array}$ & $\begin{array}{l}\text { Age }(\mathrm{Ma}) \\
\text { Data source }\end{array}$ & $\begin{array}{l}\text { Locality } \\
\text { Stratigraphy }\end{array}$ & $\begin{array}{l}\text { Depositional } \\
\text { environment }\end{array}$ & $\operatorname{MAT}\left({ }^{\circ} \mathrm{C}\right)$ & $\begin{array}{l}\text { Inferred vegetation } \\
\text { type(s) }\end{array}$ & Significant taxa \\
\hline \multicolumn{7}{|l|}{ Southeast } \\
\hline Claiborne & m Eocene & $\mathrm{TN}, \mathrm{KY}$ & $\begin{array}{l}\text { fluvial - } \\
\text { oxbow lakes }\end{array}$ & $\begin{array}{l}20-28 \\
22-30\end{array}$ & $\begin{array}{l}\text { tropical dry } \\
\text { deciduous }\end{array}$ & $\begin{array}{l}\text { Lauraceae, legumes, transition } \\
\text { oaks, Araceae, palms }\end{array}$ \\
\hline $\begin{array}{l}\text { Dilcher (1973), } \\
\text { Wolfe (1978), } \\
\text { Wolfe \& Poorle } \\
(1982)\end{array}$ & palynology & Claiborne Fm & & & & \\
\hline Catahoula & e Oligocene & east TX & $\begin{array}{l}\text { fluvial - } \\
\text { deltaic }\end{array}$ & unknown & $\begin{array}{l}\text { tropical dry } \\
\text { deciduous }\end{array}$ & $\begin{array}{l}\text { Legumes, transition \& modern } \\
\text { oaks, palms }\end{array}$ \\
\hline Galloway (1977) & palynology & Catahoula Fm & & & & \\
\hline \multicolumn{7}{|l|}{ Rocky Mountains } \\
\hline & $\begin{array}{l}\text { e m Eocene } \\
48.13 \pm 0.71\end{array}$ & east UT, west CO & lacustrine & 16 & $\begin{array}{l}\text { savanna woodland } \\
\text { tropical dry forest }\end{array}$ & $\begin{array}{l}\text { Palms, legumes, Lygodium, } \\
\text { Sapindus }\end{array}$ \\
\hline $\begin{array}{l}\text { Graham (1999), } \\
\text { Malchus et al. } \\
\text { (2002) }\end{array}$ & $\begin{array}{l}48.22 \pm 0.71 \\
{ }^{40} \mathrm{Ar} /{ }^{39} \mathrm{Ar} \text { laser } \\
\text { fusion }\end{array}$ & $\begin{array}{l}\text { Green River Fm, } \\
\text { Parachute Creek Member }\end{array}$ & & & $\begin{array}{l}\text { at lower elevations; } \\
\text { deciduous - } \\
\text { middle; mixed } \\
\text { hardwood } \\
\text { coniferous - upper }\end{array}$ & $\begin{array}{l}\text { Cedrelospermum*, Populus*, } \\
\text { Pseudosalix } *, \text { Sygioides*, } \\
\text { Gilisenium } *\end{array}$ \\
\hline $\begin{array}{l}\text { Florissant } \\
\text { Evanoff et al. } \\
(2001) ; \text { Meyer } \\
(2003)\end{array}$ & $\begin{array}{l}\text { 1 Eocene } \\
34.07 \pm 0.01 \\
\text { single crystal } \\
{ }^{40} \mathrm{Ar} /{ }^{39} \mathrm{Ar} \text { sanidine } \\
\text { from pumice in ss } \\
\text { \& debris flow }\end{array}$ & $\begin{array}{l}\text { central CO } \\
\text { Florissant Fm } \\
\text { lower and middle shales } \\
\end{array}$ & $\begin{array}{l}2 \text { lacustrine } \\
\text { episodes, } \\
1 \text { fluvial unit } \\
\text { between }\end{array}$ & 12.5 & $\begin{array}{l}\text { savanna - } \\
\text { woodland, tropical } \\
\text { - dry }\end{array}$ & $\begin{array}{l}\text { Cedrelospermum, Fagopsis, } \\
\text { Florissantia, Rosaceae }\end{array}$ \\
\hline $\begin{array}{l}\text { Creede } \\
\text { Wolfe \& Schorn } \\
\text { (1989), Ratte \& } \\
\text { Steven (1967) }\end{array}$ & $\begin{array}{l}\text { 1 Oligocene } \\
27.2 \\
\text { K-Ar of ash-flow } \\
\text { tuffs }\end{array}$ & $\begin{array}{l}\text { southwest CO } \\
\text { Creede Fm }\end{array}$ & $\begin{array}{l}\text { deep lake } \\
\text { lacustrine - } \\
\text { deltaic }\end{array}$ & 4.5 & $\begin{array}{l}\text { chaparral, } \\
\text { woodland, western } \\
\text { montane coniferous }\end{array}$ & $\begin{array}{l}\text { Rosaceae, Pines, Juniper, } \\
\text { Mahonia, Ribes, Populus, } \\
\text { Nuphar, legumes, Abies }\end{array}$ \\
\hline \multicolumn{7}{|l|}{ Pacific northwest } \\
\hline $\begin{array}{l}\text { Chuckanut } \\
\text { S. Johnson (1982 } \\
\text { 1984a), Mustoe \& } \\
\text { Gannaway (1997), } \\
\text { Mustoe et al. (2007) }\end{array}$ & $\begin{array}{l}\text { m Eocene } \\
49.9 \pm 1.2 \\
\text { Fission track of } \\
\text { tuff bed above } \\
\text { )basal contact }\end{array}$ & $\begin{array}{l}\text { Coastal \& Interior northwest } \\
\text { WA } \\
\text { Chuckanut Fm } \\
\text { Bellingham Bay \& Slide Mem } \\
\text { (lo) } \\
\text { Padden Mem (up) }\end{array}$ & $\begin{array}{l}\text { fluvial - } \\
\text { flood basin }\end{array}$ & $\begin{array}{l}15 \text { B Bay } \\
(66) ; 16 \\
\text { Slide (30); } \\
12 \text { Padden } \\
(64)\end{array}$ & $\begin{array}{l}\text { Bellingham Bay } \\
\text { and Slide: tropical } \\
\text { Padden: more } \\
\text { temperate }\end{array}$ & $\begin{array}{l}\text { Coryphoid palms, ferns: } \\
\text { Lygodium, Woodwardia, } \\
\text { Cyathea, Glyptostrobus, } \\
\text { Taxodium, Mseocyparis, } \\
\text { Metasequoia, Alnus, Betula, } \\
\text { Platanus }\end{array}$ \\
\hline $\begin{array}{l}\text { Puget Group } \\
\text { Wolfe (1968, } \\
\text { 1978); Burnham } \\
(1990,1994)\end{array}$ & $\begin{array}{l}1 \text { Eocene } \\
\text { Radiometric dates } \\
\text { and } \\
\text { biostratigraphy }\end{array}$ & $\begin{array}{l}\text { Coastal west WA } \\
\text { Puget Group }\end{array}$ & $\begin{array}{l}\text { fluvial and } \\
\text { overbank }\end{array}$ & $15-18.6$ & tropical & $\begin{array}{l}\text { Diverse ferns, Zelkova, } \\
\text { Metasequoia, monocot leaves, } \\
\text { Acer, Populus }\end{array}$ \\
\hline $\begin{array}{l}\text { Republic localities } \\
\text { Wolfe \& Wehr } \\
\text { (1987), Wolfe } \text { et al. } \\
\text { (2003), Greenwood } \\
\text { et al. (2005) }\end{array}$ & $\begin{array}{l}\text { e-m Eocene } \\
49.42 \pm 0.54 \\
{ }^{40} \mathrm{Ar} /{ }^{39} \mathrm{Ar}\end{array}$ & $\begin{array}{l}\text { Okanogan High } \\
\text { north central WA } \\
\text { Klondike Mtn Fm, Tom } \\
\text { Thumb Tuff Mem }\end{array}$ & lacustrine & $11.4,10$ & $\begin{array}{l}\text { mixed hardwood } \\
\text { coniferous early } \\
\text { western montane } \\
\text { coniferous }\end{array}$ & $\begin{array}{l}\text { Rosaceae, Acer, Ulmus, } \\
\text { Langeria, Tsukada, Macginitiea, } \\
\text { Pinus, Abies Corylus, } \\
\text { Trochodendron }\end{array}$ \\
\hline $\begin{array}{l}\text { One Mile Creek } \\
\text { Greenwood } \text { et al. } \\
\text { (2005), Dillhoff } \text { et } \\
\text { al. }(2008)\end{array}$ & $\begin{array}{l}\text { e Eocene } \\
52.08 \pm 0.12 \\
\text { U-Pb zircons }\end{array}$ & $\begin{array}{l}\text { Okanogan High south central } \\
\text { BC } \\
\text { Hardwick SS }\end{array}$ & lacustrine & $9.3,8.3$ & $\begin{array}{l}\text { mixed hardwood } \\
\text { coniferous early } \\
\text { western montane } \\
\text { coniferous }\end{array}$ & $\begin{array}{l}\text { Betula leopoldae*, } \\
\text { Cercidiphyllum, Pinus, Abies, } \\
\text { Acer, Neviusia, Prunus, Ulmus }\end{array}$ \\
\hline $\begin{array}{l}\text { Thomas Ranch } \\
\text { Greenwood et al. } \\
\text { (2005), Dillhoff et } \\
\text { al. }(2008)\end{array}$ & $\begin{array}{l}\text { e Eocene } \\
52.08 \pm 0.12 \\
\text { U-Pb, zircons }\end{array}$ & $\begin{array}{l}\text { Okanogan High } \\
\text { south central BC }\end{array}$ & lacustrine & $9.3,8.3$ & $\begin{array}{l}\text { mixed hardwood } \\
\text { coniferous early } \\
\text { western montane } \\
\text { coniferous }\end{array}$ & Conifers, Azolla, Acer \\
\hline
\end{tabular}


Table 1. continued

\begin{tabular}{|c|c|c|c|c|c|c|}
\hline $\begin{array}{l}\text { Flora } \\
\text { Main references }\end{array}$ & $\begin{array}{l}\text { Age }(\mathrm{Ma}) \\
\text { Data source }\end{array}$ & $\begin{array}{l}\text { Locality } \\
\text { Stratigraphy }\end{array}$ & $\begin{array}{l}\text { Depositional } \\
\text { environment }\end{array}$ & $\operatorname{MAT}\left({ }^{\circ} \mathrm{C}\right)$ & $\begin{array}{l}\text { Inferred vegetation } \\
\text { type(s) }\end{array}$ & Significant taxa \\
\hline $\begin{array}{l}\text { McAbee } \\
\text { Dillhoff et al. } \\
(2005)\end{array}$ & $\begin{array}{l}\text { e-m Eocene } \\
51 \pm 2 \text { to } \\
52 \pm 2\end{array}$ & $\begin{array}{l}\text { Okanogan High } \\
\text { south central BC } \\
\text { Kamloops Group, unnamed } \\
\text { fm }\end{array}$ & lacustrine & $9.5(45)$ & $\begin{array}{l}\text { mixed hardwood } \\
\text { coniferous early } \\
\text { western montane } \\
\text { coniferous }\end{array}$ & Betulaceae, Fagaceae, Ulmaceae \\
\hline $\begin{array}{l}\text { Quilchena } \\
\text { Mathewes \& } \\
\text { Greenwood (2007) }\end{array}$ & $\begin{array}{l}\text { e Eocene } \\
51.5 \pm 0.4 \\
{ }^{40} \mathrm{Ar} /{ }^{39} \mathrm{Ar} \\
\text { sanidine tephra }\end{array}$ & $\begin{array}{l}\text { Okanogan High } \\
\text { south central BC }\end{array}$ & $\begin{array}{l}\text { lake \& } \\
\text { swamp } \\
\text { complex }\end{array}$ & Unknown & $\begin{array}{l}\text { mixed hardwood } \\
\text { coniferous early } \\
\text { western montane } \\
\text { coniferous }\end{array}$ & $\begin{array}{l}\text { Taxodium, Keteleeria } \\
\text { Calocedrus, Nyssa, } \\
\text { Glyptostrobus, Metasequoia, } \\
\text { Decodon }\end{array}$ \\
\hline $\begin{array}{l}\text { Falkland R. } \\
\text { Smith et al. (2007) }\end{array}$ & $\begin{array}{l}50.61 \pm 0.16 \\
\mathrm{U}-\mathrm{Pb} \text { zircons }\end{array}$ & $\begin{array}{l}\text { Okanogan High } \\
\text { south central BC }\end{array}$ & lacustrine & 9.2 LMA & $\begin{array}{l}\text { mixed hardwood } \\
\text { coniferous early } \\
\text { western montane } \\
\text { coniferous }\end{array}$ & $\begin{array}{l}\text { Glyptostrobus, Ginkgo, } \\
\text { Macginitiea, Prunus, Acer, } \\
\text { Dipteronia, Ulmus }\end{array}$ \\
\hline $\begin{array}{l}\text { Princeton Chert } \\
\text { Stockey (2001), } \\
\text { Little et al. (2009) }\end{array}$ & $\begin{array}{l}\text { m Eocene } \\
48.7 \\
\text { K-Ar of ash layer } \\
\# 22\end{array}$ & $\begin{array}{l}\text { Okanogan High } \\
\text { south central BC } \\
\text { Princeton Group, Allenby Fm }\end{array}$ & lake or mire & unknown & subtropical & $\begin{array}{l}\text { Ferns, Monocots, Pines, Eorhiza, } \\
\text { Nymphaeaceae, Lythraceae, } \\
\text { Rosaceae, Lauraceae, Vitaceae, } \\
\text { Metasequoia* }\end{array}$ \\
\hline $\begin{array}{l}\text { Clarno Nut Beds } \\
\text { Manchester (1994) }\end{array}$ & $\begin{array}{l}\text { m Eocene } \\
\text { vertebrate } \\
\text { biostratigraphy }\end{array}$ & $\begin{array}{l}\text { Pacific Northwest Interior } \\
\text { central OR Clarno Fm }\end{array}$ & $\begin{array}{l}\text { stream and } \\
\text { lake delta }\end{array}$ & $\begin{array}{l}16, \text { based } \\
\text { on W } \\
\text { Branch } \\
\text { Creek }\end{array}$ & $\begin{array}{l}\text { tropical to } \\
\text { paratropical }\end{array}$ & $\begin{array}{l}\text { Juglandaceae, Cornaceae, } \\
\text { Icacinaceae, Platanaceae } \\
\text { Menispermaceae, }\end{array}$ \\
\hline $\begin{array}{l}\text { Appian Way } \\
\text { Little et al. (2001), } \\
\text { Mindall et al. } \\
\text { (2009) } \\
\end{array}$ & $\begin{array}{l}\text { Eocene } \\
\text { palynology; } \\
\text { decopod } \\
\text { crustaceans, } \\
\text { mollusks and shark } \\
\text { teeth }\end{array}$ & $\begin{array}{l}\text { Pacific Northwest Coastal, } \\
\text { Vancouver Is, BC } \\
\end{array}$ & $\begin{array}{l}\text { forest litter } \\
\text { in marine } \\
\text { nodules }\end{array}$ & unknown & paratropical? & $\begin{array}{l}\text { Ferns, Moss, Fagaceae, } \\
\text { Cupressaceae, Icacinaceae, } \\
\text { Platanaceae, Juglandaceae }\end{array}$ \\
\hline $\begin{array}{l}\text { Badger's Nose } \\
\text { Myers (2006) }\end{array}$ & $\begin{array}{l}\text { 1 Eocene } \\
34-35 \\
\mathrm{~K} / \mathrm{Ar} ;{ }^{40} \mathrm{Ar} /{ }^{39} \mathrm{Ar}\end{array}$ & $\begin{array}{l}\text { Pacific Northwest Interior, } \\
\text { northeast CA } \\
\text { Steamboat Fm }\end{array}$ & lacustrine & 13.8 & $\begin{array}{l}\text { intermediate warm } \\
\text { subtropical/cool } \\
\text { temperate, } \\
\text { woodland }\end{array}$ & $\begin{array}{l}\text { Betulaceae, Rhamnaceae, } \\
\text { Tiliaceae, Acer, Deviacer } \\
\text { Metasequoia, Alnus, Decodon, } \\
\text { Mahonia }\end{array}$ \\
\hline $\begin{array}{l}\text { Bridge Creek } \\
\text { Meyer \& } \\
\text { Manchester (1994) }\end{array}$ & $\begin{array}{l}\text { e Oligocene } \\
33.6\end{array}$ & $\begin{array}{l}\text { Pacific Northwest Interior } \\
\text { central OR }\end{array}$ & lacustrine & $10-12$ & deciduous & $\begin{array}{l}\text { Metasequioa, Alnus, } \\
\text { Cunninghamia, Asterocarpinus, } \\
\text { Paracarpinus, Acer, } \\
\text { Florissantia, Eucommia }\end{array}$ \\
\hline
\end{tabular}

Acer, Platanus, Pterocarya and Zelkova also occur. A MAT of $16{ }^{\circ} \mathrm{C}$ has been calculated for the Green River flora (Graham 1999).

Among the most informative occurrences at Green River are of specimens that show organic attachments of flowers, fruits, and leaves to the same stem, thereby confirming the identity of these organs as belonging to the same plant. These studies often reveal mosaic combinations of characters not seen in extant taxa, and provide clues to the evolutionary history of families. Examples include Cedrelospermum (Manchester 1989); Populus (Manchester et al. 1986); Pseudosalix (Boucher et al. 2003); Syzygioides (Manchester et al. 1998), and the herbaceous Gilisenium (Lott et al. 1998). An atlas of the Parachute Creek flora is available as an online resource (K. Johnson et al. 2002; see http://www.paleocurrents.com).

\section{Middle Eocene Pacific Northwest: Chuckanut, Swauk and Puget Group}

The Pacific Northwest contains some of the most complex geological history in North America. During the Late Cretaceous, a stable platform formed by the accretion of terraines in western Washington State. The platform underwent extensive strikeslip faulting and deformation during the early to middle Eocene to form a series of sedimentary basins. These basins experienced rapid subsidence and provided a depositional environment capable of accommodating extensive amounts of nonmarine sediments. Thick sequences of strata were produced associated with intrabasinal volcanics and intrusional, crystalline bodies (S. Johnson 1985, Brownfield et al. 2005). One of the thickest of these nonmarine sequences is the Chuckanut Formation, which 
Table 2. Flora of the Claiborne Formation.

\begin{tabular}{|c|c|c|c|}
\hline Family & Taxon & Reference & Localities \\
\hline Aracaceae (Coryphoideae) & Amesoneuron sp. & Daghlian (1978) & Lawrence \\
\hline Aracaceae (Coryphoideae) & Costapalma philipii & Daghlian (1978) & Lamkin \\
\hline Aracaceae (Coryphoideae) & Palmicites eocenica & Daghlian (1978) & Several sites \\
\hline Aracaceae (Coryphoideae) & Palustrapalma agathae & Daghlian (1978) & Several sites \\
\hline Aracaceae (Coryphoideae) & Sabalites grayensis & Daghlian (1978) & Many sites \\
\hline Aracaceae (Coryphoideae) & Sabal dortchii & Daghlian (1978) & Lamkin \\
\hline Araceae & Philodendron limnestis & Dilcher \& Daghlian (1977) & Several sites \\
\hline Araliaceae & Dendropanax eocenensis & Dilcher \& Dolph (1970) & Lawrence, New Haven, Warman \\
\hline Ceratophyllaceae & Ceratophyllum incertum & Herendeen et al. (1992) & Fayette Co. TN \\
\hline Eucommiaceae & Eucommia eocenica & Call \& Dilcher (1977) & Bovay, Idalia, LaGrange \\
\hline Euphorbiaceae & Hipppomaneoideae warmanensis & Crepet \& Daghlian (1982) & Warman \\
\hline Euphorbiaceae & Crepetocarpon perkinsii & Dilcher \& Manchester (1988) & \\
\hline Fagaceae & Berryophyllum & Jones \& Dilcher (1988) & \\
\hline Juglandaceae & Oreoroa claibornensis & Dilcher \& Manchester (1986) & Lamkin, Puryear, Somerville, Warman \\
\hline Juglandaceae & Eokachyra aeolius & Crepet et al. (1975) & Several sites \\
\hline Juglandaceae & Eoengelhardtia puryearensi & Dilcher et al. (1976) & Puryear \\
\hline Juglandaceae & Paraoremunnea puryearsnsis & Dilcher et al. (1976) & Lamkin, Puryear \\
\hline Juglandaceae & Paraoremunnea stoneana & Dilcher et al. (1976) & Lamkin, Warman \\
\hline Lauraceae & Ocotea obtusifolia & Dilcher (1963a) & Puryear \\
\hline Leguminosae Papilionoideae & Eomimosoidea plumosa & Herendeen \& Dilcher (1990a) & Warman \\
\hline Leguminosae Papilionoideae & Diplotropis claibornensis & Herendeen \& Dilcher (1990b) & Bell City, Warman \\
\hline Leguminosae Caesalpinioideae & Crudia grahamiana & Herendeen \& Dilcher (1990c) & Lawrence, Warman \\
\hline Leguminosae Caesalpinioideae & Crudia brevifolia & Herendeen \& Dilcher (1990c) & Lawrence, Warman \\
\hline Leguminosae Caesalpinioideae & Caesalpinia claibornensis & Herendeen \& Dilcher (1991) & Puryear, Warman \\
\hline Nyssaceae & Nyssa eolignitica & Dilcher \& McQuade (1967) & Lawrence, Puryear \\
\hline Oleoaceae & Fraxinus wilcoxiana & Call \& Dilcher (1992) & Puryear, Warman \\
\hline Podocarpaceae & Podocarpus & Dilcher (1969) & not listed \\
\hline Proteaceae? & Knightiophyllum wilcoxianum & Dilcher \& Mehrotra (1969) & Puryear \\
\hline Rhamnaceae & Rhamnus marginalis & Jones \& Dilcher (1980) & Puryear, Lawrence, Lamkin \\
\hline Rubiaceae & Paleorubioceophyllum eоcenicum & Roth \& Dilcher (1979) & $\begin{array}{l}\text { Puryear, Miller, Lawrence, New Lawrence, } \\
\text { Rancho, Lamkin }\end{array}$ \\
\hline Theaceae & Gordonia lamkinensis & Grote \& Dilcher $(1989,1992)$ & Lamkin, Miller \\
\hline Theaceae & Gordonia warmanensis & Grote \& Dilcher $(1989,1992)$ & Warman \\
\hline Theaceae & Gordoniopsis polysperma & Grote \& Dilcher $(1989,1992)$ & Lawrence \\
\hline Ulmaceae & Eoceltis dilcheri & Zavada \& Crepet (1981) & Lawrence, Puryear \\
\hline
\end{tabular}

is exposed in the vicinity of Bellingham, Washington and extends northeastward to the Canadian border. A second sequence, the Swauk Formation, outcrops on the flanks of the Cascade Mountains to the southeast and has been interpreted as part of the Chuckanut Formation that was faulted (Mustoe 2001, Mustoe et al. 2007). This interpretation is supported by the floristic and lithologic similarities between the two formations.

The Chuckanut Formation consists of about $9000 \mathrm{~m}$ of conglomerate, arkosic sandstone, siltstone and coal and is best exposed in western Whatcom and Skagit counties, in northwestern Washington State, where it unconformably overlies accreted Paleozoic and Mesozoic terrains (Mustoe \& Gannaway 1995, 1997; Mustoe et al. 2007). S. Johnson (1984a, 1984b) interpreted the sequence as representing a braided-meandering river system with point bar deposits being represented by crossbedded arkose beds associated with sandy units indicating crevasse splay deposits. Plant fossils are richest in siltstone beds interpreted as flood basin deposits, with lacustrine sediments rare in the sequence (Mustoe et al. 2007). While the Swauk Formation to the southeast has been consistently dated as Eocene since the time of Knowlton (1893), the age of the Chuckanut has been a matter of debate. 
The Chuckanut was thought to be the nonmarine extension of the marine Nanaimo Group and therefore of late Cretaceous to Paleocene age (Mustoe et al. 2007). It is now clear that the Chuckanut is not related to these marine units. The Chuckanut Formation has been dated by several means. A fission track age of $49.9 \pm 1.2 \mathrm{Ma}$ is based on a tuff bed approximately $2,600 \mathrm{~m}$ above the basal contact (S. Johnson 1984a). Other radiometric dates determined for the formation fall outside the main outcrop belt in areas of uncertain stratigraphy (see Fig. 3 of Mustoe et al. 2007). Detrital zircons show that the oldest Chuckanut beds are no older than late Paleocene, while volcanic interbeds are late Eocene in age.

The Chuckanut can be divided into three units, the older Bellingham Bay and younger Slide Member and a third and uppermost unit, the Padden Member. The Bellingham Bay and Slide Members have similar megathermal assemblages, while the flora in the Padden Member is distinct from them. The Bellingham Bay and Slide Members include a diverse fern component that was described by Marie Pabst (1968). Pabst studied the flora as a whole but was unable to complete her work before her death in 1963. Taxa include both temperate ferns such as Lygodium, Pteris, Woodwardia, and Dennsteadtia, as well as the tree fern Cyathea which today is found primarily in tropical to subtropical areas. The flora also includes the taxodiaceous conifers Glyptostrobus, Taxodium, Mesocyparis, and Metasequoia. Sabalites palms are common, along with dicot elements such as Alnus, Betula, Platanus and Quercus banksiaefolia (Mustoe \& Gannaway 1997, Mustoe et al. 2007). The Bellingham Bay flora is subtropical and estimated to have a MAT of $15^{\circ} \mathrm{C}$ based on a CLAMP analysis of 66 leaf morphotypes, while that of the Slide Member was estimated at $16^{\circ} \mathrm{C}$ based on 30 morphotypes (Mustoe \& Gannaway 1997). In contrast, the younger Padden Member flora lacks palms, ferns and lowland conifers and instead contains small-leafed dicots and has an estimated MAT of $12{ }^{\circ} \mathrm{C}$ based on CLAMP of 64 morphotypes (Mustoe \& Gannaway 1997, Mustoe et al. 2007).

The Swauk Formation and related plant-bearing units (including the late Eocene Roslyn and Chumstick Formations) follow the northwest-southeast trending Cascade Mountains. Tropical coastal floras west of the Cascades are very similar to that of the lower Chuckanut members. In contrast, those east of the Cascades, floras of the Roslyn and Chumstck Formations typically lack palms and some of the other tropical elements (Mustoe 2001). These floras are not well published, however, note Mustoe \& Gannaway (1995, 1997), Mustoe (2001, 2002a), and Pigg \& Wehr (2002).

Additional megathermal floras are known from the late Eocene Puget Group, an undivided unit in the Green River Area of southwest Washington that is associated with four other significant coal-producing units. All five of these sequences represent deposition in a variety of shallow-marine, brackish, deltaic and fluvial environments (Burnham 1986, 1990, 1994; Reineck \& Singh 1980; Brownfield et al. 2005). The Puget Group has a large proportion of fluvial and/or distributary channel and overbank deposits. Regionally, nonmarine rocks increase in abundance upsection and prograding is recorded throughout the Eocene. The Puget Group overlies unexposed basement rock and underlies a sequence of volcanics at the very end of the late Eocene. Comparisons with the time-equivalent Skookumchuck Formation near Centralia, Washington place the age of the Puget Group as late Eocene (Brownfield et al. 2005).

Plants from the Puget Group were studied by Wolfe (1968) who described 31 genera including 25 new taxa. Burnham (1994) updated the taxonomic list to include around 45 genera and numerous morphotypes (see Burnham 1994, Appendix 4). Among the taxa included are Equisetum, ferns including Asplenium, Dryopteris, Allantodiopsis, Cyathea, Dennstaedtia, and Salvinia, taxodiaceous conifers Metasequoia and Glyptostrobus, several types of monocot leaves including Zingiberopsis, and among dicots Acer, Betula, Castanopsis, Fraxinus, Populus, Salix, Vitis, Zelkova, and leaves of affinities to the families Cercidiphyllaceae, Euphorbiaceae, Juglandaceae, Lauraceae, and possibly Menispermaceae.

\section{The Okanogan Highlands}

To the northeast of the Chuckanut and Swauk Formations is a region based on early-middle Eocene strata known as the Okanogan Highlands ("Okanagan" in Canada; Archibald \& Greenwood 2005). These deposits formed after the geological processes described below: Extensive strikeslip faulting occurred in northeast Washington during the late early to early middle Eocene. During this time, the southern Cordillera of northernmost central Washington, and up into south-central British Columbia, experienced episodes of right-lateral faulting responsible for producing a set of northwest-trending grabens and half-grabens (Ewing 1981, Matthews 1991, Mustoe 2005). A volcanic arc in south-central British Columbia provided a source of large volumes of volcaniclastic sediments and basalt flows in these basins. In the quiescent periods between volcanic activity, a rich array of fossil fish, insects and plants were preserved. The preserving lacustrine and fluvial sediments typically are described as clastic, however Mustoe (2005) has suggested that geochemical alternation of diatomaceous deposits may be responsible in part for the production of these siliceous shales.

In contrast to the coastal Chuckanut Formation and Puget Group, the Okanogan localities today exist at elevations ranging from 500-1100 $\mathrm{m}$ and, are believed to have been at, or above, this present elevation during the Eocene (Archibald \& Greenwood 2005). Major plant assemblages 
of the Okanogan Highlands occur at Republic and at Princeton, Quilchena, Falkland, and MacAbee, British Columbia [BC]. Smaller and/or less collected sites are found at Horsefly and Driftwood Creek, BC, and a variety of other locations (Archibald \& Greenwood 2005, Greenwood et al. 2005, Mustoe 2005, Pigg et al. 2007, R. Smith et al. 2007).

The best known and most diverse of the Okanogan Highlands floras is from a series of localities in and near Republic, Washington, in the Klondike Mountain Formation (Wing 1987, K. Johnson 1996). First considered a primarily conifer-dominated flora (Wolfe \& Wehr 1987, Schorn \& Wehr 1996), Wolfe \& Wehr (1987) named 24 dicots (exclusive of Ulmaceae) from Republic. Since then, and largely through the collecting efforts of Stonerose Interpretive Center in Republic, massive numbers of leaf, fruit, seed and insect specimens have been collected. Republic is known now to have over 250 plant genera, the majority of them represented by dicot leaves and reproductive structures (Wehr 1995, Wehr \& Manchester 1996, Pigg \& Wehr 2002). The Republic flora is illustrated at the Burke Museum of Natural History \& Culture website at: http://www.washington.edu/burkemuseum/collections/paleontology/stonerose/.

Two sites with significant leaf compression floras that occur near Princeton, BC, in the Allenby Formation are the One Mile Creek locality (also known as Allison Creek) and the Thomas Ranch site (also known as Tulameen Road; Dillhoff et al. 2008). One Mile Creek is dominated by leaves, fruits, and pollen catkins of Betula leopoldae (Crane \& Stockey 1986). Other common elements are leaves of Cercidiphyllum, Acer fruits (Wolfe \& Tanai 1987), Abies, Prunus, and well preserved cones and needle fascicles of Pinus. This flora is currently under study and is more diverse than previously thought, with 70 morphotypes representing 57 species (Dillhoff et al. 2008). The Thomas Ranch site is well known for the whole Azolla plants that occur in paper shale containing gypsum crystals (Arnold 1955). To date, a total of 66 morphotypes have been recognized at this site, representing aroud 56 species (Dillhoff et al. 2008).

The McAbee site near Cache Creek, BC has been collected and studied in detail recently by Richard and Thomas Dillhoff, and is represented online at the Evolving Earth Foundation website at: http://www.evolvingearth.org/paleocollaborator/index.php.

The McAbee site is dominated by numerous conifers, Fagus leaves and nuts (Manchester \& Dillhoff 2004), fruits and leaves of Ulmus (Denk \& Dillhoff 2005), Betula, and Alnus (Dillhoff et al. 2005). This site contrasts with Quilchena, which is considered the "warmest and wettest" of the Okanogan Highlands sites (Mathewes \& Greenwood 2007). Quilchena has been dated at 51.5 Ma with a mesothermal MAT of $15{ }^{\circ} \mathrm{C}$ (Greenwood et al. 2005). This flora differs from other Okanogan Highlands floras in having several thermophilic taxa that are absent at the other sites including Keeteleria, Taxodium and Nyssa (Mathewes \& Greenwood 2007). Well preserved fruits and abundant seeds of Decodon are also present (Mathewes, pers. comm. 2005). The Falkland site is dated at $50.61 \pm 0.16$, or early Eocene with a MAT of $9.2 \pm 2.2{ }^{\circ} \mathrm{C}$ (using LMA, based on 38 leaves, R. Smith et al. 2007). A paleocological study of this site is in progress (R. Smith et al. 2007). Recent summaries on the floristics, depositional environment, and biogeography of the Okanogan Highlands compression floras include: Archibald \& Greenwood (2005), DeVore et al. (2005), Dillhoff et al. (2005), and Pigg \& DeVore (2007). DeVore \& Pigg (2007) have reviewed the western North American occurrences of Rosaceae, concentrating on the Okanogan Highlands.

Although many paleobotanists are interested in floral components that have diversified and radiated within the tropics there has been little attention paid to the origin and evolution of temperate families. The Okanogan Highlands floras are important in this regard because they contain the earliest known occurrences for many temperate genera (e.g., Corylus, Carpinus, Amelanchier, Neviusia, and Corylopsis; Wehr \& Hopkins 1994, K. Johnson 1996, Pigg et al. 2003, DeVore et al. 2004, Radtke et al. 2005). New taxonomic work has been completed from several of these floras: at Republic: Trochodendraceae (Trochodendron, Nordenskioldia, Tetracentron, Pigg et al. 2001b, 2007); Betulaceae (Corylus, Carpinus, and Palaeocarpinus, Pigg et al. 2003); at One Mile Creek: Rosaceae (Nevuisia, DeVore et al. 2004); Betulaceae (Palaeocarpinus, Pigg et al. 2003); Hamamelidaceae (Corylopsis and Fothergilla; Radtke et al. 2005), and Trochodendraceae (Tetracentroni, Pigg et al. 2007); and at McAbee: Ginkgo (Mustoe 2002b); Fagaceae (Fagus, Manchester \& Dillhoff 2004), Ulmaceae (Ulmus, Denk \& Dillhoff 2005), Trochodendraceae (Trochodendron, Pigg et al. 2007), and the "Eocene mystery plant" Dillhoffia (Manchester \& Pigg 2008). Ongoing studies include the description of Prunus flowers (Benedict et al. 2008), and Nuphar flowers, stigmatic discs and seeds (Wehr \& Manchester 1996, DeVore \& Pigg 2008), both from Republic.

\section{Late Eocene floras in the Pacific Northwest}

Several additional late Eocene floras of interest in the Pacific Northwest include the megathermal coastal floras at La Porte and Susanville in northern California (Potbury 1935, Wolfe 1978), and the Goshen and Comstock floras of central Oregon (Chaney \& Sanborn 1933, Sanborn 1935). These sites are typically referred to as tropical rainforests with MATs of $24-27{ }^{\circ} \mathrm{C}$ (or around $20{ }^{\circ} \mathrm{C}$ with CLAMP; see Graham 1999). In contrast, late Eocene floras to the 
east of north/south trending mountains include the Thunder Mountain flora of central Idaho (Axelrod 1998) and the Copper Basin flora of northeastern Nevada (Axelrod 1966b, Wing 1987), both of which are described as mixed hardwood-coniferous floras with a MAT of around $11{ }^{\circ} \mathrm{C}$ (Graham 1999). The latest Eocene Badgers Nose flora in far northeastern California is an "in-between" flora with an intermediate combination of elements including megathermal "Goshen type" magnoliaceous and lauraceous leaves along with plants of the early Oligocene deciduous "Bridge Creek type" such as Alnus, Parrotia, Cercidiphyllum and Metasequoia (Myers 2006).

\section{Eocene permineralized floras}

Three floras that provide detail about the anatomical structure of Eocene plants are known in the Pacific Northwest. The first is the Princeton chert from near Princeton, south central British Columbia. This flora was initially studied by James Basinger and, since the early 1980s, by Ruth Stockey, students and colleagues. This locality consists of 49 interbedded chert and coal layers with occasional ash beds. Some of the cherts split and anastomose, resulting in around 70 layers altogether (Little et al. 2009). Stratigraphically, the chert is found within the Princeton Group, Allenby Formation, and was initially dated as middle Eocene by Hills \& Baadsgaard (1967) using potassium argon dating. A recently resampled date obtained by Baadsgaard was 48.7 Ma from ash layer \# 22 (see Little et al. 2009).

The Princeton chert has been interpreted variously as a swamp or mire with different layers containing several distinct assemblages. Many of the plants are aquatic and are thought to be essentially autochthonous (Cevallos-Ferriz et al. 1991, Klymiuk et al. 2009). This interpretation is based on the growth position of rhizomatous Eorhiza stems (Stockey \& Pigg 1994), aerenchymatous plant tissues (e.g., Dennsteadtiopsis), and affinities with extant aquatics including Decodon, Nymphaeaceae, and Araceae. Certain layers have assemblages of moncots and conifers. Other elements (e.g., Rosaceae, Magoliaceae, Vitaceae) are much rarer and are thought to have been transported (Cevallos-Ferriz et al. 1991).

Over 30 plants have been described from the Princeton chert (Basinger \& Rothwell 1977, Pigg \& Stockey 1996, Stockey 2001). Included are five types of ferns (Stockey et al. 1999, Karafit et al. 2006, S. Smith et al. 2006). Conifers are represented by the taxodiaceous Metasequoia milleri (see below), Pinus arnoldii (Miller 1973), pine leaves of several types and pollen cones. Dicots include fruits and seeds of Cornaceae, Lauraceae, Lythraceae, Nymphaeaceae, Myrtaceae, Rosaceae and Vitaceae; wood is known of Magnoliaceae and Prunus. Six types of monocots are known, and numerous fungi (not discussed).
Of the most completely preserved plant remains in this flora, Metasequoia milleri (Cupressaceae) has been reconstructured as a whole plant (Basinger 1981, 1984; Rothwell \& Basinger 1979). A complete series of floral buds, flowers and fruits are known for Princetonia allenbyensis (Stockey 1987, Stockey \& Pigg 1991), a taxon of unknown affinities, and the vegetative plant body has been described for the rhizomatous semiaquatic Eorhiza (Robison \& Person 1973, Stockey \& Pigg 1994) which is hypothesized to be the parent plant of Princetonia. Other flowers that have been described include those of the extinct Paleorosa (Basinger 1976, Cevallos-Ferriz et al. 1993); Wehrwolfea (Erwin \& Stockey 1990) and an extinct species of Sarurus (S. Smith \& Stockey 2007a, b). In addition to detailed floral structure, these flowers all have in situ pollen. Fruits, seeds, stems and roots are known of the aquatic Decodon (Lythraceae) (Cevallos-Ferriz \& Stockey 1988; Little \& Stockey 2003, 2005). Additional lythraceous leaves at Princeton are more similar to those of the mangrove plant Duabanga, suggesting either that a second genus is present or that the plant with Decodon reproductive and other vegetative features was a mosiac taxon with distinctive leaves (Little et al. 2004).

\section{Clarno}

A discussion of the Eocene of the Northwest would be incomplete without a mention of the important middle Eocene floras of the Clarno Formation. These floras are located in the John Day Basin of north central Oregon, in the same region as the early Oligocene Bridge Creek flora (see below). Best known among these sites are the Clarno Nut Beds, which have been described in detail by Manchester (1994). The Clarno Nut Beds contain anatomically preserved fruits and seeds e.g., Juglandaceae, Platanaceae), many of which are of subtropical families such as Icacinaceae and Menispermaceae. This flora has numerous taxonomic similarities with the London Clay (Reid \& Chandler 1933, Collinson 1983) and Messel floras (Manchester 1994, 1999; Collinson et al. 2010). Of the compression floras closely associated with the Clarno Formation, the West Branch Creek site is described as a tropical to paratropical locality with a calculated CLAMP of $16^{\circ} \mathrm{C}$ (Graham 1999). Also significant is a recently completed study of the Clarno woods, summarizing wood occurrences of additional taxa and providing support to determinations made from the fruit and seed record (Wheeler \& Manchester 2002). The Clarno woods provide one of the few known examples of a diverse assemblage of fossil wood types that can be directly linked with fruit and seed remains.

A third Eocene locality in the Pacific Northwest with anatomically preserved plants, fungi and marine faunal elements has been described from the Appian Way site south 
of the Campbell River on the eastern coast of Vancouver Island, BC. The Appian Way plants, fungi and faunal remains occur in marine calcarous nodules in a sandy siltstone matrix and are interpreted as representing a shallow marine environment (Mindall et al. 2009). The age of the unit has not been clearly established. Based on palynology it is late Paleocene to early Eocene (Sweet 1997). More recent studies based on decopod crustaceans, mollusks and shark teeth suggest middle to late Eocene age (Schweitzer et al. 2003). Stratigraphic studies are still in progress (Cockburn \& Haggart 2007, Mindell et al. 2009). Nodules containing the fossil wood, fruits and seeds have clearly been transported and abraded (Little et al. 2001). Based on the association of plant remains found together, the plant parts found within nodules are thought to be torn up fragments of forest vegetation that became buried rapidly in high energy coastal deposits (Steenbock et al. 2009).

The Appian Way flora is of value for its beautifully preserved anatomical structure. Among the taxa that have been described are a moss gametophyte (Steenbock et al. 2009), two filicalean ferns (Gleichenia and Paralygodium, Mindall et al. 2005, Trivett et al. 2006) and taxodiaceous conifers (Hernandez-Castillo et al. 2005, Ramírez-Peña et al. 2009). Dicots include members of the Platanaceae, Fagaceae, Junglandaceae, and Icacinaceae (Elliot et al. 2006; Mindall et al. 2006, 2007, 2009; Rankin et al. 2008). Additional families that are represented include Annonaceae, Magnoliaceae, and Cornaceae, as well as over a dozen additional unidentified forms (Little et al. 2001). Based on the taxa published to date and a broader preliminary overview, the Appian Way flora appears to have quite a few similarities with the Clarno Nut Beds and the London Clay (Little et al. 2001, Rankin et al. 2008, Mindall et al. 2009).

\section{Late Eocene in the Rocky Mountains}

Florissant flora. - The late Eocene basin formed by Lake Florissant of central Colorado provides one of the few occurrences for fossil floras in the Rocky Mountains after the middle Eocene (Leopold \& MacGinitie 1972). MacGinitie (1953) produced a detailed treatment of the Florissant in which 114 species of fruits and leaves were described. In 1967, to protect this significant locality from land development, the Florissant Fossil Beds National Monument was established, ensuring that the rich record of vertebrates, insects, and fossil plants would be protected for future study. A volume providing status on the Florissant was prepared in 2001 (Evanoff et al. 2001), and subsequent years have seen numerous symposia dedicated to the site (e.g., Meyer 2004).

The Florissant Formation represents a diverse assemblage of lithologies including coarse-grained units of arkosic and volcanoclastic sandstones and conglomerates and finer units of shale, tuffaceous mudstone and siltstone (Evanoff et al. 2001). These sediments were deposited in a paleovalley that was periodically blocked by lahars, producing lacustrine deposits. There are two lacustrine episodes: the lower shale unit represents the first while the caprock conglomerate marks the beginning of the second. A fluvial unit, containing fossil mammals and the famous fossil Sequoia stumps in the lower mudstones, marks the interval between the two lacustrine stages. Each lacustrine stage was terminated by first pumice gravel and later lahar breccias. Well-preserved fish and insects as well as leaves and plant reproductive organs are present in the lower shale unit, middle shale unit (just above the fluvial unit) and upper shale unit (Niesen 1969, Wobus \& Epis 1978, Evanoff et al. 2001). Most of the well-known and best-preserved plant fossils come from the middle shale unit, which is the main quarry interval within the Florissant Fossil Beds National Monument (Evanoff et al. 2001).

The single crystal ${ }^{40} \mathrm{Ar} /{ }^{39} \mathrm{Ar}$ analysis of sanidine from pumice in sandstone and debris flow deposits of the upper Florissant Formation yielded an age of $34.07 \pm 0.01 \mathrm{Ma}$ (Evanoff et al. 2001), placing the Florissant Formation within the latest Eocene. The age is bounded by the underlying Wall Mountain Tuff dated at $36.7 \mathrm{Ma}$ and overlying volcanics at 34.07 Ma. The presence of brontotheres from the upper section of the fluvial sequence between the two lacustrine episodes (lower mudstone unit) supports this age since brontotheres become extinct at, or near, the Eocene/Oligocene boundary (Obradovich et al. 1995). The presence of both brontotheres, as well as Mesohippus place the formation in the Chadronian NAMLA (Evanoff et al. 2001).

The flora of the Florissant has been summarized by MacGinitie (1953), updated by Manchester (2001), and beautifully illustrated by Meyer (2003), and we refer the reader to these references for details. The two most abundant angiosperm taxa are Cedrelospermum and Fagopsis. Cedrelospermum is based on Zelkova-like leaves found in attachment to stems bearing distinctive winged fruits, and is interpreted as an early successional species occupying the margin of Lake Florissant (Manchester 1989, Meyer 2003). Fagopsis is known only from the western North American Eocene and is the most abundant leaf type found at Florissant (Manchester \& Crane 1983). These leaves, which superficially resemble Fagus, are found in attachment to stems with distinctive pistillate and staminate inflorescences that are unlike any known Fagaceae (Manchester \& Crane 1983). The most unusual feature of Fagopsis is its pistillate inflorescence. About forty wedge-shaped units, homologous to fagaceous cupules and each containing three nuts, are spirally attached to an elongate receptacle. The wedge-shaped cupulate units are often found as strings and apparently were released as they unraveled from the inflorescence and may have been wind dispersed (Meyer 2003). Quercus is also well represented with nine species, and includes what 
appears to be a mixture of both evergreen and deciduous type, many with affinities to oaks of the extant Southwest and northern Mexico (Meyer 2003).

The Rosaceae are also important components of the Florissant flora and have the greatest diversity of any family at the generic level (MacGinitie 1953, Wolfe 1987, Manchester 2001, Meyer 2003, DeVore \& Pigg 2007). Florissant has some of the earliest occurrences of leaves and fruits of $c f$. Cercocarpus and Crataegus, leaves of Holodiscus (Schorn 1998), and Rosa leaves, fruits and stems with prickles (Meyer 2003). Examples of other rosaceous genera at Florissant that are also known from other earlier localities include Rubus, Malus, Prunus, and possibly Vauquelinia.

Although flowers are relatively rare in these fossil floras, the durable calyx of Florissantia was readily preserved and the fruits, still attached to the calyx and receptacle, serve as a dispersal unit (Manchester 1992). This distinctive malvalean flower has been found at Bridge Creek, and Republic, where specimens bearing petals have been recovered. Florissantia has yet to be recognized outside of North America and appears to be endemic to the Rocky Mountains and Okanagan Highlands floras.

Although angiosperms dominate the flora, it is the array of conifers at Florissant that is probably the most conspicuous, including the large stumps of Sequoia that made Florissant a popular tourist spot from the 1920s through early 1960s (Meyer 2003). In addition to Sequoia, $\mathrm{Cu}-$ pressaceae is represented by Chamaecyparis, and there are five species of Pinus in sections Pinus and Strobus. Taxaceae is represented by Torreya, which has a record based on its dispersed needles.

The most surprising aspect of Florissant is the relatively poor record of ferns and other pteridophytes. Two species of Equisetum have been reported, but the only filicalean fern described is Dryopteris guyottii (Meyer 2003). Unlike other fossil floras where many ferns occur in relatively dense stands (e.g., Onoclea, Rothwell \& Stockey 1989; Woodwardia, H. Smith 1938), it appears that pteridophytes inhabited dispersed microhabitats surrounding Lake Florissant. It is uncertain whether pteridophytes were lacking or were never captured by the depositional environment.

Leaf and pollen records were integrated to interpret the paleoenvironment represented at Florissant (Leopold \& Clay-Poole 2001). Results suggested that the climate in the Lake Florissant region was warm-temperate to subtropical with moderate summer rainfall and mild, dry winters. The NLR method gave an estimate of MAT no lower than $17.5^{\circ} \mathrm{C}$, which is $4-6.8^{\circ}$ warmer than CLAMP or multiple regression estimates (Leopold \& Clay-Poole 2001). This estimate may reflect the fact that NLR data emphasize conditions immediately surrounding the lake. New records of taxa (Manchester 2001) were also added that indicate that some Florissant plants show connections with extant taxa living in the warm-temperate zone of China, and in the eastern United States to the Ozark Plateau. These findings also support MacGinitie's belief that the montane elements of the Florissant flora (Pinaceae and Fagaceae) show affinities to taxa from the highlands in northeastern Mexico, and that scrub taxa were established in steep ecological gradients at Florissant.

\section{Oligocene floras}

Pacific Northwest: Bridge Creek. - In western North America, there are few Oligocene floras. The most significant are the early Oligocene Bridge Creek flora of the John Day Formation, central Oregon and the late Oligocene Creede flora (see below) of southwestern Colorado. The Bridge Creek flora is extraordinarily rich with 91 genera; 58 species known from fruits, seeds and cones and 110 species based on leaves (Meyer \& Manchester 1997). Radiometric dates for ages of the assemblages at Bridge Creek range from 31.8 Ma (Painted Hills, K/Ar, Hay 1962) to $33.6 \pm$ $0.19 \mathrm{Ma}$ (Iron Mountain, ${ }^{40} \mathrm{Ar} /{ }^{39} \mathrm{Ar}$, Swisher \& Prothero 1990). The John Day Formation is lies uncomformably above the middle Eocene Clarno Formation.

The Bridge Creek flora occurs at seven different localities in the lower John Day Formation. These localities can be grouped into three "facies assemblages" as defined by Meyer \& Manchester (1997). They include: (1) The Eastern Facies, at Painted Hills and Butler Basin; (2) the Southern Facies, at Crooked River and Lost Creek and (3) the Western Facies at Cove Creek, Fossil and Iron Mountain; Chaney 1924; Robinson et al. 1984, 1990; Meyer \& Manchester 1997).

The John Day Formation is believed to represent depositional environments associated with a back-arc setting. Three sources of sediments contributed to the lithology of units present. Basaltic and trachyandesite flows near the back-arc setting are local, while rhyolitic ash-flow tuffs east of the present-day Cascades and pyroclastics from the western Cascade Range, represent distal sources of sediments (Robinson et al. 1984, 1990; Meyer \& Manchester 1997). The fine-grained volcanic ash redeposited in lacustrine basins provided an ideal depositional environment for preserving an array of leaves and reproductive structures.

The Bridge Creek flora has an estimated MAT of 9-11 ${ }^{\circ} \mathrm{C}$ and is interpreted as a broadleaf deciduous assemblage (Graham 1999). Siginificant plants in this flora include Metasequoia (Chaney 1924), Cunninghamia, Acer, Amelanchier, Alnus, Betula, Cercidiphyllum, Cercis, cf. Crataegus, Eucommia, Fagus, Florissantia, Ostrya, Pteleocarpum, cf. Pyracantha, Rosa (leaves, fruits and prickles), Rubus, and the families Platanaceae, Tiliaceae, and Ulmaceae. The extinct betulaceous genus Asterocarpinus and its associated leaf type Paracarpinus have also been described from Bridge Creek (Manchester \& Crane 1987). 
Additional Oligocene floras of the Pacific Northwest. - Several other Oligocene floras in the Pacific Northwest include the Rujada and Gumboot Mountain floras (Meyer \& Manchester 1997, Pigg \& Wehr 2002). The Rujada Flora from west central Oregon has a MAT of $12-13{ }^{\circ} \mathrm{C}$ and a mix of broadleaf deciduous, broadleaf evergreen and coniferous taxa (Lakhanpal 1958). The Gumboot Mountain flora, which outcrops south of Mount St. Helena is known from the Oligocene of Washington State. In their monograph on the Bridge Creek flora, Meyer \& Manchester (1997) list the following taxa as present at Gumboot Mountain: Abies, Cunninghamia, Metasequoia, Sequoia, Pinus, Florissantia, Platanus, Pterocarya, Tilia, Ribes and Acer, as well as taxa within Fagaceae and Rosaceae. One interesting occurrence exclusively at Gumboot Mountain is that of Exbucklandia (Hamamelidaceae; Manchester 1999, Pigg \& Wehr 2002). In addition to the compression floras, several permineralized conifer cones have been described from the Twin River Group, a marine unit, of the northern Olympic Peninsula (C. Miller 1989, 1990).

\section{Late Eocene-early Oligocene in the Rocky Mountains}

Montana. - Mention should be made of the southwestern Montana late Eocene to Oligocene floras described, in large part, by Herman Becker. These include the Beaverhead Basins, York Ranch, Metzel Ranch, and Ruby River Basin (Becker 1961, 1969, 1972, 1973). Becker originally interpreted these floras as being of Oligo-Miocene age, but more recent studies have demonstrated their late Eocene to Oligocene age (Graham 1999). Precise ages are not known for these floras. The Beaverhead Basins flora is interpreted as a latest Eocene lacustrine deposit of comparable age to Florissant. Dominant dicots include Quercus, Mahonia, Acer, Salix, Betula, Cassia and Zelkova and the main conifers are Abies and Picea. Metzel Ranch and York Ranch are considered early Oligocene in age and represent low energy floodplain, pond and lake environments. In contrast to older Beaverhead Basins and the younger Ruby River Basin, the Metzel and York Ranch localities lack oaks and have few conifers, lacking Picea and Abies. These two floras are dominated by Rosaceae, Rhamanaceae, legumes and also have junipers, grasses and Mahonia, suggesting lower elevation, drier habitats. The slightly younger Ruby River Basin flora, which Becker (1961) refers to as being from intermontane lacustrine deposits, bears some similarities to Florissant, but lacks many of the more mesic elements such Florissantia, Cedrelospermum, Acer, and Fagopsis. As in the Pacific Northwest, isolated anatomically preserved conifer cones have been described from western Montana (e.g., C. Miller 1969, 1970).
Creede. - The Creede Formation consists of an assemblage of predominantly lacustrine beds deposited in a deep lake occupying the Creede caldera in southwestern Colorado. Lithologies present include sequences of conglomerates, sandstones, siltstones, limestones, travertine and both airborne and reworked tuffs (Finkelstein et al. 1999, Larsen \& Smith 1999). Localities yielding significant fossil plant material have been interpreted as being preserved in beds deposited close to the delta front, or within depositional environments close to a steep shore. Other areas, such as the Wason Cliffs section, likely represent deposition from small streams that had downcut into a landslide in the northeastern section of the caldera. Plant-bearing tuffs present in the 5-bridge section occur interbedded with sandstones that could represent an extension of the high-energy environment into the lake (Wolfe \& Schorn 1989). The Creede localities have recently been interpreted as a set of environments where coarse-grained deposition is associated with lacustrine basins with sublacustrine-fan deposits. Clearly, Lake Creede was influenced by a complex interplay among the tectonic and volcanic history of the region and local climatic, geochemical and hydrological conditions (Finkelstein et al. 1999, Larsen \& Smith 1999). Wolfe \& Schorn (1989) accepted a radiometric date of 27.2 (Ratte \& Steven 1967; correction made for recent decay constants), placing the formation in the late Oligocene.

The Creede represents the only well documented late Oligocene flora of the southern Rocky Mountains and has been systematically treated by Axelrod (1987) and Wolfe \& Schorn (1990). Conifers include five species of Pinus, and one each of Abies, Picea, and Juniperus (Wolfe \& Schorn 1990). The most diverse dicot family is the Rosaceae which includes leaves of genera assigned to Spiraeaoideae, Stockeya, a genus with affinities to Chamaebatiaria, Sorbus, Cratageus, Potentilla, Cercocarpus (with possible achenes), "?Osmaronia" (= Oemleria), and, rarely, Prunus (Axelrod 1987; Wolfe \& Schorn 1989, 1990; DeVore \& Pigg 2007). Other angiosperm families include Berberidaceae (Berberis, Mahonia), Salicaceae and Bignoniaceae, legumes and Grossulariaceae (3 species of Ribes).

The paleoecological distribution of taxa in the Creede flora was analysed using multivariate statistical techniques (Wolfe \& Schorn 1989), and four major plant associations were recognized. The first association is a fir-spruce (Abies-Picea) forest estimated to have occupied regions $170 \mathrm{~m}$ above Lake Creede. Associates include the shrubs Berberis and Ribes. The second community is defined by the co-occurrence of Abies and Pinus in association with Mahonia and Ribes, with Cercocarpus also appearing. (3) The third association is the pine-juniper forest, representing an open-canopy or woodland. Here the dominant shrub is Cercocarpus, although Mahonia is also present. (4) The final association is a mountain mahogany chaparral that is interpreted as nearly treeless zone occupying a floodplain 
dominated by Cercocarpus. Wolfe \& Schorn (1989) concluded that all the taxa comprising these four communities had histories connected with Paleogene montane vegetation in the Rocky Mountains and have lineages recognized in the fossil record from Florissant, Ruby and Salmon as well as in the Okanagan Highland floras.

\section{Spatial and temporal distribution of paleogene cycads and palms in North America}

Analyses of leaf physiognomy (CLAMP, LMA, LA) are based exclusively on dicot leaf assemblages. Two important groups of plants with a Paleogene presence that are not included in these analyses are palms and cycads. Nevertheless, they play a significant role in Eocene and Oligocene floras of North America and provide additional opportunity for paleoclimatic inference.

\section{Cycads}

Cycad fossils in North America have been described from the Mississippi Embayment, the northern Rocky Mountains and Western Interior, and the Pacific Northwest including Alaska. Forms similar to Zamia were described for the Eocene of southeastern North America, Puerto Rico, and the Virgin Islands (Hollick 1932). Zamia is known from Paleocene fluvial deposits in the Western Interior and Rocky Mountains areas formerly occupied by the Cretaceous Intercontinental Seaway (R. Brown 1962). In the Rocky Mountains a "whole plant reconstruction" of a cycad has been documented from the highly diverse, tropical flora of the Early Paleocene Castlerock locality in central Colorado (I. Miller et al. 2007). Well-documented cycad leaves with cuticle, some attributed previously to the fern genus Allantodiopsis, were described from Paleocene floras of Wyoming and the Eocene Clarno Formation of Oregon (Kvaček \& Manchester 1999). In the Pacific Northwest fossils resembling Ceratozamia and two species of Dioon were reported from the Eocene of Alaska (Hollick 1932). The most intriguing North American locality where cycad leaves have been reported is the Republic flora of northeastern Washington (Hopkins \& Johnson 1997). This report is based on two isolated pinnules that resemble modern Zamia and Ceratozamia. Typically, cycads are assumed to be limited to tropical and subtropical regions, therefore it is curious that they occur at Republic, a locality estimated to have a MAT of $10-13{ }^{\circ} \mathrm{C}$, a cold month mean of less than 1 ${ }^{\circ} \mathrm{C}$, and a paleoelevation estimated to be between 727-909 m (Wolfe \& Wehr 1987) and 900-1100 (Archibald \& Greenwood 2005). Presumably, microhabitats occur at the Republic site that allowed for thermophilic taxa.
Cycads appeared in the fossil record at least by the Permian and are usually associated with warm, subtropical environments (Kvaček \& Manchester 1999, Kvaček 2002). Because of their long history and rich fossil record during the Mesozoic, as well as the disjunct occurrences of many extant genera, there is a tendency to characterize the present distribution of cycads as relictual. However, when viewed in the context of phylogeny based on extant taxa, modern cycads appear to result from recent radiations among crown taxa. Since some groups appear post PETM, Cenozoic populations may have been impacted by later, less intense warm periods.

This hypothesis is yet to be fully tested. A critical examination of the Cenozoic record is needed since the relationships between Cenozoic and modern taxa are unclear. Some fossil forms have a mosaic of characters not present in modern taxa. Still others could be erroronously attributed to ferns (e.g., Allantodiopsis). Despite these difficulties, there is no compelling evidence to indicate that modern cycads are relict taxa. A stronger hypothesis is that they represent the recent evolution of terminal lineages in a group deeply rooted in the fossil record.

\section{Fossil record of coryphoid palms in North America}

The palm genus Sabal (subtribe Coryphoideae) has a current North American distribution similar to that of the cycad Zamia. The two genera occupied the same regions during the Tertiary. The systematics of extant Sabal is well known and can be integrated with the fossil record to assess the biogeographical history in some detail.

Gulf Coast coryphoid fossil palms from the early and middle Eocene include five well-defined genera (Daghlian 1978). Sabal, Sabalites, Costapalma, Palmacites, and Palustrapalma were recognized on the basis of leaf morphology and detailed cuticular studies. Sabal dortchii is an Eocene plant with well-preserved cuticle that shows the stomatal complex morphology indicative of the genus. Sabalites grayanus and Costaplalma philipii are coryphoid palms but they cannot be placed in the modern genus Sabal. While Sabal, Sabalites and Costapalma are all costapalmate forms, Palustrapalma and Palmacites are palmate forms that possess a mosaic of characters, including those found in genera from Clade 4 (Fig. 1, see below). A sixth genus, Amesoneuron, was established for palm leaves that lack definitive taxonomic characters (Daghlian 1978). Coryphoid palms remain in the coastal plains of the Mississippi Embayment into the Oligocene where they are found in the Catahoula Formation of east Texas (Daghlian et al. 1980).

In the Great Plains and northern Rocky Mountains, fossil sabaloid leaves have been documented from Paleogene 
floras (R. Brown 1962, Hickey 1977) including well-preserved specimens from extensive lacustrine deposits of the Green River Basin. Presently, Sabal or Sabalites leaves of Oligocene age are unknown from the region.

In the Pacific Northwest, coryphoid palms assigned to Sabalites are known from Eocene localities, extending from the Gulf of Alaska (Wolfe 1977) to the Chalk Bluffs flora of coastal California (McGinitie 1941). Some of the most spectacular remains are the nearly entire fronds of Sabalites campbelli from the Chuckanut Formation of Washington (Mustoe \& Gannaway 1997). Coryphoid palms are also known from the anatomically preserved Princeton chert. The genus Uhlia was established for permineralized stem fragments with attached petiole bases and roots that were found in association with isolated petioles, midribs, laminae and roots (Erwin \& Stockey 1994). Uhlia is interpreted as having similarities to the extant genera Rhadophyllum and Brahea, but having a combination of characters not in concert with any extant genus within the subfamily.

Sabalites persisted into the Oligocene in the Northwest and has been described from the Rujada flora of Oregon (Lakhanpal 1958) and Eagle Creek flora of Washington (Chaney 1920). In southern California, fossil palm taxa persisted into the Miocene and Pliocene (Tuta 1967) where today the only native extant forms are three species of Washingtonia (Mustoe \& Gannaway 1997). Natural populations of Washingtonia filifera also are known in the Kofa Mountians and southern Yavapai County of western Arizona, where they are thought to be relicts (D. Brown et al. 1976). Based on the distribution of fossil taxa of Sabal and Sabalites, this lineage of palms dispersed during the Tertiary along coastal plains associated with the Mississippian Embayment, the Intercontinental Seaway, and in coastal plains in the Pacific Northwest, including a broad embayment extending into central Oregon and Washington. All three of these regions are fluvial paleoenvironments, on broad flood plains, at relatively low elevations suggesting that coryphoid plans persisted in similar habitats throughout the Tertiary.

\section{Phylogeny of extant Sabal}

Based on the phylogenetic relationships and distributions of extant species, Zona (1990) hypothesized that Sabal had a North American origin. A later study (Santiago-Valentin \& Olmstead 2004) incorporated data from both Zona's (1990) monographic work and molecular phylogenetic analysis (Asmussen et al. 2000) to generate an area cladogram. In this phylogenetic biogeographical analysis of Caribbean plants, a basal position was indicated for Sabal minor, a species distributed in the southeastern United States (indicated as Clade 1 in Fig.1). In this analysis, S. minor is sister to a second clade (Clade 2 in Fig. 1) consisting of four species found in the Bahamas, Bermuda, Cuba and southeastern United States. These two basal clades are distinct from a third clade of three western Mexican species (Clade 3 in Fig. 1) and the fourth, most derived clade in the genus (Clade 4 in Fig. 1). This fourth clade consists of six taxa distributed in Central America, Central Mexico, Cuba, Jamaica, Hispaniola, and Puerto Rico. The sister group to Sabal has been identified as a clade consisting of Chelyocarpus, Coccothrinax, Crysophila, Thrinax, and Trithrinax. This sister clade has an inferred ancestry in South America, based on extant members (Asmussen et al. 2000, Santiago-Valentin \& Olmstead 2004).

\section{Integrating the coryphoid palm fossil record and phylogeny with biogeography}

Bjorholm et al. (2006) synthesized data from the worldwide fossil record of sabaloid palms (including Europe and Asia), the phylogeny of extant Sabal and the current geographic distribution of the genus. In this study, a regression analysis was performed to evaluate the importance of environmental and spatial variables on distributional pattern. The study suggested that the richness patterns for Coryphoideae reflect historical, rather than environmental factors. The paleoenvironments preserving Sabal and Sabalites all are low elevation fluvial or lacustrine environments. It seems unlikely that basal Sabal have shared an immediate common ancestor with those from western Mexico (Fig. 1).

We include an illustration of the distribution patterns of modern clades of Sabal superimposed onto a paleogeographic map of middle Eocene age; $50 \mathrm{Ma}$ (Fig. 1). The cladogram to the right is from Zona (1990).

After examining the records from Paleodatabase (accessed 2007) for these taxa in North America, it became apparent that their distribution corresponds with the former position of the Intercontinental Seaway and both its eastern and western coastal regions. The implication of this for estimating dispersal from North America into the Caribbean and northern South America is significant. It seems unlikely that basal Sabal species distributed in the southeastern United States, Bahamas, Bermuda and Cuba could have shared an immediate common ancestor with those from western Mexico. If there were a single introduction, Sabal species would have had to disperse up through higher elevations to re-enter the Caribbean. Instead, it seems more plausible that the genus was introduced at least once via the Mississippian Embayment and at least once via the Pacific (Fig. 1). The widespread distribution of Sabal and Sabalites in Asia and Europe could potentially mean that the basal members of Sabal shared a lineage with European species while the more derived lineages in Mexico are aligned with a Pacific lineage. 


\section{Nypa and Mangrove Associations}

A second palm, the Old World mangrove Nypa (sometimes spelled Nipa) today has an Indo-Australian distribution, but in the past, was clearly a significant member of mangrove communities with a worldwide distribution (Reid \& Chandler 1933, Collinson 1983, Gee 2001). This plant was a dominant component of the early Eocene London Clay and also occurred throughout other European sites including in the Brussels area and the Paris Basin (Collinson 1993). In North America Nypa pollen assigned to Spinizonocolpites first appears in the Gulf Coast in Alabama and Georgia from the early Eocene Tallahatta Formation of the Wilcox Group (Frederiksen 1980, 1981, 1988). The first megafossil record of Nypa in North America comes from the Popes Creek Flora of Maryland (Tiffney 1999), also during the early Eocene. Subsequent records of Nypa and Spinizonocolpites show this palm subfamily reaching its maximum range in the Gulf regions (Casa Blanca Flora) by the middle Eocene before having its range contract back to Alabama, Georgia and Mississippi during the late Eocene. There are no known records of Nypa in North America during or after the Oligocene (Gee 2001).

In addition to documenting the fossil record of the genus Nypa, it is instructive to look at the fossil record at a community level for the mangrove assemblages within which Nypa typically occurs. Based on palynofloras, Graham (1995) documented the following floristic progression in mangrove communities of Gulf/Caribbean regions throughout the Ceonozoic. 1) First, an early Eocene community occurred defined by four principal genera (including Acrostichum, Brevitricolpites variabilis, and Pelliceria); 2) Aviennia first appears in the Miocene; 3) By the middle Pliocene mangrove communities diversify to six mangroves (Acrostichum, Avicennia, Crenea, Laguncularia, Pelliceria, and Rhizophora) with three associated genera (Acacia, Hampea/Hibiscus, and Pachira); members of the black (Avicenniaceae), red (Rhizophoraceae) and white mangroves (Combretaceae) became the prominent mangrove taxa in the region; and 4) Further diversification through the Quaternary includes the dominant mangrove genus Concarpus with further additions continuing into the present day community consisting of approximately 27 genera of mangroves and associates.

Mangrove taxa have evolved a highly specialized suite of characters to thrive in habitats inhospitable to most other angiosperms. Highly specialized features and modifications of both anatomical and morphological type, as well as altered physiology, are not easily reversed back to the initial states these features evolved from. In essence, like aquatic plants, mangroves most likely could not evolve out of the mangrove habitat. Because they occupy such coastal environments as tidal inlets and coastal lagoons, they are in a position to readily disperse their propagules. Their persistence and ranges today represent their ability to be distributed by cur-

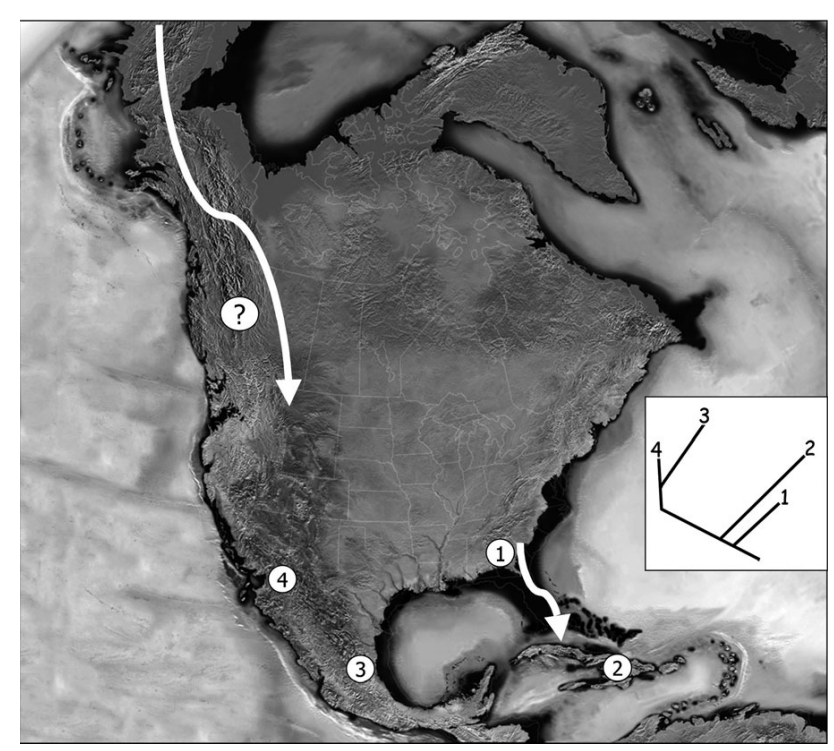

Figure 1. Middle Eocene reconstruction (50 Ma) of North America with the position of the four clades of extant Sabal (1-4) shown in relation to current distribution of the genus (from Zona 1990). • Clade 1 - Sabal minor. Arrow indicates dispersal of this basal clade into the Caribbean. - Clade 2 - four species found in the Bahamas, Bermuda, Cuba and southeastern United States. $\bullet$ Clade 3 - three western Mexican species. $\bullet$ Clade 4 - six taxa distributed in Central America, Central Mexico, Cuba, Jamaica, Hispaniola, and Puerto Rico. The arrow to the left with the question mark indicates potential dispersal of the more derived taxa in Clade 4 from the Pacific region. Phylogenetic information from Zona (1990). Paleomap redrawn from Blakey (2005).

rents into new, favorable habitats. Thus, current distributions of mangrove taxa not only reflect their evolutionary history, but also the chance arrival of new species in a region.

\section{Conclusions}

Late Eocene and Oligocene plant fossil localities in North America can be tracked in three major regions: the Southeast (Mississippian Embayment); the Pacific Northwest; and the central Rocky Mountains. In the Mississippian Embayment the differences between the middle Eocene Claiborne and the early Oligocene Catahoula floras are subtle. Selected elements from the diverse and well collected Claiborne are also found in the less known Catahoula. Both floras have palms, legumes and transitional oaks, although lauraceous leaves are less common in the Catahoula. Given the shear amount of collecting that has taken place for many years from numerous commercial clay pits in the Claiborne, the diversity might be expected to be considerably greater than what is known from the less studied Catahoula.

In the Pacific Northwest, floras are known from the middle Eocene coastal Chuckanut and Swauk formations and late Eocene Puget Group, and the early-middle Eocene upland floras of the Okanogan Highlands. Fewer Oligocene floras are known, most notably the Bridge Creek flora of 
Oregon, and Gumboot Mountain in Washington State. The coastal floras of the Puget Group, and Chuckanut floras occurring west of the Cascades, have megathermal assemblages with palms, lauraceous leaves and ferns at their localities except for the youngest Padden Member which lacks palms and diverse ferns. Similar patterns of coastal megathermal and interior cooler temperature floras occur through the end of the Eocene. The diverse "upland" floras of the Okanogan Highlands are dominated by microthermal elements, although some warm temperate elements (e.g., cycads, see above) have been reported (Archibald \& Greenwood 2005, Hopkins \& Johnson 2007).

Several floral elements, primarily from the Okanogan Highlands, persist into the late Eocene Florissant and early Oligocene Bridge Creek floras including Abies, Pinus, Cercidiphyllum, Acer, Florissantia, Betula, and Tilia. Among the Rosaceae, some genera that have their earliest appearance at Republic (e.g., Amelanchier, cf. Crataegus, Rubus, cf. Pyracantha) are known in greater diversity in the Florissant and at Bridge Creek, while others, such as Rosa are first seen in western North America at Florissant. Fagus, once thought to be of Oligocene origin, is now known from the early Eocene McAbee site (Manchester \& Dillhoff 2004). Taxa that first appear in Bridge Creek include Ostrya, Paracarpinus, Asterocarpinus, and Cercis. Uniquely, the Oligocene flora at Gumboot Mountain has infructescences of the genus Exbucklandia (Hamamelidaceae; Manchester 1999, Pigg \& Wehr 2002).

In the Rocky Mountains, the middle Eocene is represented by the Green River flora, the late Eocene by Florissant, and the late Oligocene by the Creede flora. The Green River shares many megathermal elements with plants of the Claiborne Formation that are lost by late Eocene times when mesic elements dominate the diverse lacustrine Florissant assemblage. By the Late Oligocene, the Creede flora is dominated by cooler and drier taxa including Rosaceae, pines, legumes, Abies, Picea and Juniperus (Axelrod 1987, Wolfe \& Schorn 1990). Vegetative assemblages of the Creede foretell the later dry conifer and chaparral floras that cover much of western North America today.

\section{Questions for future work}

Lastly, we offer a series of what we feel are important questions to be addressed with future work on the late Eocene and Oligocene floras of North America.

\section{How do you integrate leaf physiognomy and Nearest Living Relative (NLR) method?}

Some studies of late Eocene and Oligocene floras have focused on using fossil plants as a source of proxy data (MAP
\& MAT measurements) just as they have in studies tracking climate change across the Paleocene-Eocene boundary (see Pigg \& DeVore 2010). One difference we see in floras of the late Eocene and Oligocene is the appearance of more fossil taxa that can be assigned to extant genera, such that the Nearest Living Relative method might be used with more confidence (Graham 1999). In particular, studies that incorporate the NLR method for taxa not scored for leaf physiognomic studies such as ferns, conifers and monocots provide an opportunity to assess estimates of paleoclimate parameters in a noncircular context.

In the present paper, we have seen examples where NLR methods estimate a temperature slightly higher than those generated by LM analyses (e.g., Florissant). However, there continue to be more efforts to integrate both NLR and leaf physiognomic methods in a meaningful way and many studies incorporate a combination of approaches. One such effort recently proposed by Yang et al. (2007) is Overlapping Distribution Analysis (ODA). This method uses both NLR and the MAT (of NLRs) methodologies, but is based on local plant distributions of living relatives and data from meteorological stations located in a determined area representing the region of overlap of the NLRs. This method was devised for climatic reconstruction of the Miocene Shanwang Basin, but may also prove useful for reconstructing climate based on late Eocene and Oligocene floras. A useful avenue of research would be exploring additional ways to integrate NLR and leaf physiognomic data so that results from each method can be used for the purpose of cross-validation of estimates of paleoclimate and paleoelevation.

\section{How do we integrate fossil data into phylogenetic studies of key taxa present in modern plant communities?}

The use of fossils to date times of divergence of phylogenies based on modern taxa is too broad a topic to discuss here and it lies outside the focus of the present paper. However, there have been detailed studies that incorporate extant-based phylogenies and the fossil record to analyze the biogeography of modern genera. One of the best examples has been studies of the Fagaceae. Manos \& Stanford (2001) integrated phylogenetic analyses based on several regions of chloroplast and nuclear ribosomal DNA of genera in the Fagaceae. They used the resulting phylogenies to generate ancestral area reconstructions based on dispersal-vicariance analysis (DIVA). They then compared these results with the fossil record of Fagaceae to estimate migration and divergence times for Castanea, Fagus, Quercus and Trigonobalanus. The use of fossils in historical biogeographical studies based on phylogenies of modern taxa is still being developed. However there are the follo- 
wing important caveats: 1) The distributional history of a group may not always be closely estimated based on a cladistic analysis of its modern relatives and their present distributions; 2) The first appearances of taxa in the fossil record may not correspond with the basalmost clade in a phylogenetic tree; and 3) Sometimes taxa that had a widespread distribution in the past (e.g. Nypa), today have a restricted distribution that is interpreted as endemic. Using fossil distributions to cross-validate biogeographical histories based on extant plants is becoming more prevalent and has been used effectively with some groups (e.g. palms, Bjorholm et al. 2006). Potentially, as more data are integrated into Paleodatabase and other similar resources, researchers whose work is focused on extant groups can easily plot records of taxa found in the fossil record onto paleogeographical reconstructions to better assess the biogeographical history of the modern plant taxa.

\section{Continued reconstruction of taxa found in Eocene-Oligocene floras.}

Several taxa that appear within late Eocene and Oligocene floras represent mosaics and transitional forms. In the case of Quercus, transitional and modern forms are found together in the early Oligocene Catahoula Formation (Crepet \& Nixon 1989b). In some cases, there are entire plant organs that are hard to interpret and relate to modern forms (Fagopsis inflorescenes). The only link between the past and the present is through morphology. Clearly, how the combinations of characters found within fossil taxa are interpreted within the context of evolutionary histories based on extant taxa will be a significant endeavor. It is after the Eocene-Oligocene boundary where we can begin to make the closest connections between some dominant angiosperm taxa today and their relatives in the fossil record.

\section{Acknowledgements}

We thank Margaret E. Collinson for inviting our participation in this symposium and edited volume, Rick and Tad Dillhoff of the Evolving Earth Foundation and Michael Sternberg and Jan Hartford for discussion of the Chuckanut floras; the Paleobiology Database; John C. Benedict and Witt Taylor for editorial assistance; Felix Gato and Wegener \& Rodney DeVore for technical assistance and Jane Maienschein for encouragement. We are especially grateful to the late Wes Wehr of the Burke Museum, Seattle; George Mustoe and Donald Hopkins; Lisa Barkesdale, Catherine Brown and Karl Volkman of Stonerose Interpretive Center; and the many volunteer collectors of the Chuckanut, Swauk, and Okanogan Highlands floras for their contributions to Eocene paleobotany in the Pacific Northwest. Funding for this work was provided by NSF EAR-0345838 to KBP and NSF EAR-0345569, and a Faculty Re- search and Development Award, GC\&SU, and a Visiting Professorship from the Center of Biology \& Society, School of Life Sciences, Arizona State University, to MLD.

\section{References}

ARChiBALD, S.B. \& GREENWOOD, D.R. 2005. The Okanagan Highlands: Eocene biota, environments, and geological setting, southern British Columbia, Canada and northeastern Washington, USA. Canadian Journal of Earth Sciences 42(2), 111-114. DOI 10.1139/e05-012

ARNOLD, C.A. 1955. A Tertiary Azolla from British Columbia. Contributions of the Museum of Paleontology of the University of Michigan 12, 37-45.

ASMUSSEN, C.B., BAKER, W.J. \& DRANSFIELD, J. 2000. Phylogeny of the palm family (Arecaceae) based on rps16 intron and trnL-trnF plastid DNA sequences, 525-537. In WILSON, K.L. \& MORRISON, D.L. (eds) Systematics and evolution of monocots. CSIRO Publishing, Collingwood, Victoria.

AXELROD, D.I. 1957. Age-curve analysis of angiosperm floras. Journal of Paleontology 31(1), 273-280.

AXELROD, D.I. 1966a. A method for determining the altitudes of Tertiary floras. Palaeobotanist 14, 144-171.

AXELROD, D.I. 1966b. The Eocene Copper Basin flora of northeastern Nevada. University of California Publications in Geological Sciences 59, 1-125.

AXELROD, D.I. 1987. The Late Oligocene Creede Flora, Colorado. University of California Publications in Geological Sciences 130, 1-235.

AXELROD, D.I. 1998. The Eocene Thunder Mountain flora of central Idaho. University of California Publications in Geological Sciences 142, 1-61.

BASINGER, J.F. 1976. Paleorosa similkameenensis, gen. et. sp. nov., permineralized flowers (Rosaceae) from the Eocene of British Columbia. Canadian Journal of Botany 54(20), 2293-2305. DOI 10.1139/b76-246

BASINGER, J.F. 1981. The vegetative body of Metasequoia milleri from the Middle Eocene of southern British Columbia. Canadian Journal of Botany 59, 2379-2410.

BASINGER, J.F. 1984. Seed cones of Metasequoia milleri from the middle Eocene of southern British Columbia. Canadian Journal of Botany 62(2), 281-289. DOI 10.1139/b84-045

BASINGER, J.F. \& ROTHWELl, G.W. 1977. Anatomically preserved plants from the Middle Eocene (Allenby Formation) of British Columbia. Canadian Journal of Botany 55, 1984-1990. DOI $10.1139 / \mathrm{b} 77-223$

BECKER, H.F. 1961. Oligocene plants from the Upper Ruby River Basin, southwestern Montana. The Geological Society of America Memoir 82, 1-127.

BECKER, H.F. 1969. Fossil plants of the Tertiary Beaverhead Basins in southwestern Montana. Palaeontographica, Abteilung B 127, 1-142.

BECKER, H.F. 1972. The Metzel Ranch flora of the Upper Ruby River Basin, southwestern Montana. Palaeontographica, Abteilung 141B, 1-61.

BECKER, H.F. 1973. The York Ranch flora of the Upper Ruby River Basin, southwestern Montana. Palaeontographica, Abteilung B 143, 18-93.

Benedict, J.C., DeVore, M.L. \& PIGG, K.B. 2008. Rosaceous flowers resembling Prunus from the Eocene Republic flora of 
eastern Washington State, USA. Botany 2008, Vancouver, BC, July 2008, Abstract.

BERRY, E.W. 1916. The Lower Eocene floras of southeastern North America. United States Geological Survey Professional Paper 91, 1-481.

BERRY, E.W. 1922. Additions to the flora of the Wilcox Group. United States Geological Survey Professional Paper 131-A, 1-21.

BERRY, E.W. 1924. The Middle and Upper Eocene floras of southeastern North America. United States Geological Survey Professional Paper 92, 1-206.

BERRY, E.W. 1925. The flora of the Ripley Formation. United States Geological Survey Professional Paper 136, 1-94.

BERRY, E.W. 1930. Revision of the Lower Eocene Wilcox flora of the southeastern states, with descriptions of new species, chiefly from Tennessee and Kentucky. United States Geological Survey Professional Paper 156, 1-196.

BERRY, E.W. 1941. Additions to the Wilcox Flora from Kentucky and Texas. United States Geological Survey Professional Paper 193-E, 83-99.

BJorholm, S.W., Svenning, J.-C., BAKER, W.J., SKOv, F. \& BALSLEV, H. 2006. Botanical Journal of the Linnaean Society 151(1), 113-125. DOI 10.1111/j.1095-8339.2006.00527.x

BLAKEY, R. 2005. Paleogeography and geological history of North America. http://jan.ucc.nau.edu/ rcb7 (accessed September 1, 2007).

BOUCHER, L.D., MANCHESTER, S.R. \& JUDD, W.S. 2003. An extinct genus of Salicaceae based on twigs with attached flowers, fruits, and foliage from the Eocene Green River Formation of Utah and Colorado, USA. American Journal of Botany 90(9), 1389-1399. DOI 10.3732/ajb.90.9.1389

BROWn, D.E., CARMONY, N.B., LOWE, C.H. \& TURNER, R.M. 1976. A second locality for native California fan palms (Washingtonia filifera) in Arizona. Arizona Academy of Science 11(1), 37-41.

BROWN, R.W. 1934. The recognizable species of the Green River flora. United States Geological Survey Professional Paper 185-C, 43-77.

BROWN, R.W. 1962. Paleocene floras of the Rocky Mountains and Great Plains. United States Geological Survey Professional Paper 375, 1-119.

BrownField, M.E., AFFOLTER, R.H., CATHCART, J.D., JOHNSON, S.Y., BROWNFIELD, I.K., RICE, C.A. \& ZIELINSKI, R.A. 2005. Geologic setting and characterization of coal and the modes of occurrence of selected elements from the Franklin coal zone, Puget Group, John Henry No. 1 mine, King County, Washington. International Journal of Coal Geology 63, 247-275. DOI 10.1016/j.coal.2005.03.021

BURNHAM, R.J. 1986. Foliar morphological analysis of the Ulmoideae (Ulmaceae) from the early Tertiary of western North America. Palaeontographica, Abteilung B 201, 135-167.

BuRnhAM, R.J. 1990. Some late Eocene depositional environments of the coal-bearing Puget Group of western Washington State, USA. International Journal of Coal Geology 15(1), 27-51. DOI 10.1016/0166-5162(90)90062-4

BURNHAM, R.J. 1994. Paleoecological and floristic heterogeneity in the plant-fossil record - an analysis based on the Eocene of Washington. United States Geological Survey Bulletin 2085-B, B1-B36.

CALL, V.B. \& DILCHER, D.L. 1992. Investigations of angiosperms from the Eocene of southeastern North America: samaras of Fraxinus wilcoxiana Berry. Review of Palaeobotany and Palynology 74(3-4), 249-266. DOI 10.1016/0034-6667(92)90010-E

CALl, V.B. \& DilChER, D.L. 1994. Parvileguminophyllum coloradensis, a new combination for Mimosites coloradensis
Knowlton, Green River Formation of Utah and Colorado. Review of Palaeobotany and Palynology 80(3-4), 305-310. DOI 10.1016/0034-6667(94)90007-8

CALL, V.B. \& DilCHER, D.L. 1995. Fossil Ptelea samaras (Rutaceae) in North America. American Journal of Botany 82(8), 1069-1073. DOI 10.2307/2446237

CALL, V.B. \& DILCHER, D.L. 1997. The fossil record of Eucommia (Eucommiaceae) in North America. American Journal of Botany 84(6), 798-814. DOI 10.2307/2445816

CARROL, A.R. \& BOHACS, K.M. 1999. Stratigraphic classification of ancient lakes: Balancing tectonic and climatic controls. Geology 27(2), 99-102.

DOI 10.1130/0091-7613(1999)027<0099:SCOALB>2.3.CO;2

CEVALlOS-FERRIZ, S.R.S., ERWIN, D.M. \& STOCKEY, R.A. 1993. Further observations on Paleorosa similkameenensis (Rosaceae) from the middle Eocene Princeton chert of British Columbia, Canada. Review of Palaeobotany and Palynology 78(3/4), 277-291. DOI 10.1016/0034-6667(93)90068-6

Cevallos-FerriZ, S.R.S. \& StOCKey, R.A. 1988. Permineralized fruits and seeds from the Princeton chert (Middle Eocene) of British Columbia - Lythraceae. Canadian Journal of Botany 66(2), 303-312. DOI 10.1139/b88-050

CeVallos-Ferriz, S.R.S., StOckey, R.A. \& PigG, K.B. 1991. The Princeton chert: evidence for in situ aquatic plants. Review of Palaeobotany and Palynology 70, 173-185. DOI 10.1016/0034-6667(91)90085-H

Chaney, R.W. 1920. The flora of the Eagle Creek Formation. Contributions to the Walker Museum 2, 115-181.

Chaney, R.W. 1924. A comparative study of the Bridge Creek flora and the modern redwood forest. Carnegie Institute of Washington Contributions to Paleontology 349, 1-22.

CHANEY, R.W. \& SANBORN, E.I. 1933. The Goshen flora of west central Oregon. Carnegie Institute of Washington Contributions to Paleontology 439, 1-103.

Cockburn, T. \& Haggart, J.W. 2007. Preliminary report on the marine fauna of the Appian Way Eocene site, p. 23. In Programme and abstracts, Seventh British Columbia Paleontological Symposium, May 18-21, Vancouver.

Collinson, M.E. 1983. Fossil plants of the London Clay. 121 pp. The Palaeontological Association, London.

Collinson, M.E. 1993. Taphonomy and fruiting biology of recent and fossil Nypa. Special Papers in Palaeontology 49, 165-180.

Collinson, M.E., MANCHESTER, S.R., Wilde, V. \& HAYES, P. 2010. Fruit and seed floras from exceptionally preserved biotas in the European Paleogene. Bulletin of Geosciences 85(1), 95-102. DOI 10.3140/bull.geosci.1155

CRANE, P.R. \& STOCKEY, R.A. 1986. Betula leaves and reproductive structures from the Middle Eocene of British Columbia, Canada. Canadian Journal of Botany 65, 2490-2500. DOI $10.1139 / \mathrm{b} 87-338$

CREPET, W.L. \& DAGHLIAN, C.P. 1980. Castaneoid inflorescences from the middle Eocene of Tennessee and the diagnostic value of pollen (at the subfamily level) in the Fagaceae. American Journal of Botany 67(5), 739-757. DOI 10.2307/2442667

CREPET, W.L. \& DAGHLIAN, C.P. 1982. Euphorboid inflorescences from the Middle Eocene Claiborne formation. American Journal of Botany 69(2), 258-266. DOI 10.2307/2443013

CREPET, W.L. \& DILCHER, D.L. 1977. Investigations of angiosperms from the Eocene of North America: a mimosoid inflorescence. American Journal of Botany 64(6), 714-725. DOI $10.2307 / 2441724$ 
CREPET, W., DILCHER, D.L. \& POTTER, F.W. 1975. Investigations of angiosperms from the Eocene of North America: a catkin with juglandaceous affinities. American Journal of Botany 62(8), 813-823. DOI 10.2307/2441892

CREPET, W.L. \& NIXON, K.C. 1989a. Earliest megafossil evidence of Fagaceae: phylogenetic and biogeographic implications. American Journal of Botany 76(6), 842-855. DOI 10.2307/2444540

CREPET, W.L. \& NIXON, K.C. 1989b. Extinct transitional Fagaceae from the Oligocene and their phylogenetic implications. American Journal of Botany 76(10), 1493-1505. DOI 10.2307/2444437

DAGHLIAN, C.P. 1978. Coryphoid palms from the Lower and Middle Eocene of southeastern North America. Palaeontographica, Abteilung B 166, 44-82.

DAGHLIAN, C.P. \& CREPET, W.L. 1983. Oak catkins, leaves and fruits from the Oligocene Catahoula Formation and their evolutionary significance. American Journal of Botany 70(5), 639-649. DOI 10.2307/2443119

DAGHLIAN, C.P., CREPET, W.L. \& DELEVORYAS, T. 1980. Investigations of Tertiary angiosperms: a new flora including Eomimsoidea plumosa from the Oligocene of eastern Texas. American Journal of Botany 67(3), 309-320. DOI 10.2307/2442341

DENK, T. \& DillhOFF, R.M. 2005. Ulmus leaves and fruits from the Early-Middle Eocene of northwestern North America: systematics and implications for character evolution within Ulmaceae. Canadian Journal of Botany 83(12), 1663-1681. DOI 10.1139/b05-122

DeVore, M.L., Moore, S.M., PIGG, K.B. \& WeHr, W.C. 2004. Fossil Neviusia leaves (Rosaceae: Kerriae) from the lower-middle Eocene of southern British Columbia. Rhodora 106(927), 197-209.

DEVore, M.L. \& PigG, K.B. 2007. A brief review of the fossil history of the family Rosaceae with a focus on the Eocene Okanogan Highlands of eastern Washington State, USA, and British Columbia, Canada. Plant Systematics \& Evolution 266(1-2), 45-57. DOI 10.1007/s00606-007-0540-3

DeVore, M.L. \& PIGG, K.B. 2008. Aquatic plants of the Eocene Republic, Washington flora and their significance to interpreting ancient lacustrine environments. Symposium: What Good are (Fossil) Plants Anyway? New Methods for Investigating Old Problems. Geological Society of America, Houston, October 2008, Abstract.

DeVore, M.L., PIGG, K.B. \& WeHR, W.C. 2005. Systematics and phytogeography of selected Okanagan Highlands plants. Canadian Journal of Earth Sciences 42(2), 205-214. DOI 10.1139/e04-072

DILCHER, D.L. 1963a. Cuticular analysis of Eocene leaves of Ocotea obtusifolia. American Journal of Botany 50(1), 1-8. DOI 10.2307/2439856

DILCHER, D.L. 1963b. Eocene epiphyllous fungi. Science 142(3593), 667-669. DOI 10.1126/science.142.3593.667

DILCHER, D.L. 1965. Epiphyllous fungi from Eocene deposits in western Tennessee, U.S.A. Palaeontographica, Abteilung B 116, 1-54.

DILCHER, D.L. 1969. Podocarpus from the Eocene of North America. Science 164(3877), 299-301. DOI 10.1126/science.164.3877.299

DILCHER, D.L. 1971. A revision of the Eocene floras of southeastern North America. The Palaeobotanist 20(1), 7-18 (published in 1973).

DILCHER, D.L. 1973. A paleoclimatic interpretation of the Eocene floras of southeastern North America. Chapter 2, 39-59. In
GRAHAM, A. (ed.) Vegetation and vegetational history of northern Latin America. Elsevier, Amsterdam.

DILCHER, D.L. \& DAGHLIAN, C.P. 1977. Investigations of angiosperms from the Eocene of southeastern North America. Philodendron leaf remains. American Journal of Botany 64(5), 526-534. DOI 10.2307/2442000

DILCHER, D.L. \& DOLPH, G.E. 1970. Fossil leaves of Dendropanax from Eocene sediments of southeastern North America. American Journal of Botany 57(2), 153-160. DOI 10.2307/2440507

DILCHER, D.L. \& MANCHESTER, S.R. 1986. Investigations of angiosperms from the Eocene of North America: Leaves of the Engelhardieae (Juglandaceae). Botanical Gazette 147(2), 189-199. DOI 10.1086/337586

DILCHER, D.L. \& MANCHESTER, S.R. 1988. Investigations of the angiosperms from the Eocene of North America: A fruit belonging to Euphorbiaceae. Tertiary Research 9(1-4), 45-68.

DILCHER, D.L. \& MCQUADE, J.F. 1967. A morphological study of Nyssa endocarps from Eocene deposits in western Tennessee. Bulletin of the Torrey Botanical Club 94(1), 35-40. DOI $10.2307 / 2483600$

DilCHER, D.L. \& MEHROTRA, B. 1969. A study of leaf compressions of Knightiophyllum from Eocene deposits of southeastern North America. American Journal of Botany 56(8), 936-943. DOI 10.2307/2440635

DilcheR, D.L., POTTER, F.W. \& CREPET, W.L. 1976. Investigations of angiosperms from the Eocene of North America: Juglandaceous winged fruits. American Journal of Botany 63(5), 532-544. DOI 10.2307/2441817

Dillhoff, R.M., Dillhoff, T.A. \& PIGG, K.B. 2008. Middle Eocene lacustrine shale floras of the Allenby Formation near Princeton, British Columbia, Canada. Symposium: World wide early and middle Eocene floras - the evolving picture. $8^{\text {th }}$ International Organisation of Palaeobotany Conference, Bonn, August-September 2008, Abstract.

DILLHOFF, R.M., LEOPOLD, E.B. \& MANCHESTER, S.R. 2005. The McAbee flora of British Columbia and its relations to the Early-Middle Eocene Okanagan Highlands flora of the Pacific Northwest. Canadian Journal of Earth Sciences 42(2), 151-166. DOI 10.1139/e04-084

ELLiOTT, L.L., Mindell, R.A. \& STOCKEY, R.A. 2006. Beardia vancouverensis gen. et sp. nov. (Juglandaceae): permineralized fruits from the Eocene of British Columbia. American Journal of Botany 93(4), 557-565. DOI 10.3732/ajb.93.4.557

ELSIK, W.C. \& DILCHER, D.L. 1974. Palynology and age of clays exposed in Lawrence Clay Pit, Henry County, Tennessee. Palaeontographica, Abteilung B 146, 65-87.

ERWIN, D.M. \& STOCKEY, R.A. 1990. Sapindaceous flowers from the Middle Eocene Princeton chert (Allenby Formation) of British Columbia, Canada. Canadian Journal of Botany 68(9), 2025-2034.

ERWIN, D.M. \& STOCKEY, R.A. 1994. Permineralized monocotyledons from the middle Eocene Princeton chert (Allenby Formation) of British Columbia: Arecaceae. Palaeontographica, Abteilung B 234, 19-40.

EVANHOFF, E., GREGORY-WODZICKI, K.M. \& JOHNSON, K.R. (eds) 2001. Fossil flora and stratigraphy of the Florissant Formation, Colorado. Proceedings of the Denver Museum of $\mathrm{Na}$ ture and Science 4(1).

EWING, T.E. 1981. Regional stratigraphy and structural setting of the Kamloops Group, south-central British Columbia. Canadian Journal of Earth Sciences 18, 1464-1477. 
FinKelstein, D.B., HAY, R.L. \& AltANER, S.P. 1999. Origin and diagenesis of lacustrine sediments, upper Oligocene Creede Formation, southwestern Colorado. The Geological Society of America Bulletin 111(8), 1175-1191. DOI 10.1130/0016-7606(1999)111<1175:OADOLS >2.3.CO;2

Freile, D., Midkiff, T., DeVore, M. \& PIGG, K. 2003. Petrographic thin section and geochemical analysis of fossil plant material and associated sediments from the Oligocene Catahoula FM, east Texas, South-Central Section $\left(37^{\text {th }}\right)$ and Southeastern Section $\left(52^{\text {nd }}\right)$. Geological Society of America Joint Annual Meeting, March 12-14, 2003, Memphis, Tennessee, Abstract.

FRIEDRICKSEN, N.O. 1980. Sporomorphs from the Jackson Group (Upper Eocene) and adjacent strata of Mississippi and western Alabama. United States Geological Survey Professional Paper 1084, 1-75.

Friedricksen, N.O. 1981. Middle Eocene to early Oligocene plant communities of the Gulf Coast U.S., 493-549. In GRAY, J. \& BOUCET, W.B.N. (eds) Communities of the Past. Hutchinson Ross, Stroudsbury, Pennsylvania.

FRIEDRICKSEN, N.O. 1988. Sporomorph biostratigraphy, floral changes and paleoclimatology, Eocene and earliest Oligocene of the eastern Gulf Coast. United States Geological Survey Professional Paper 1448, 1-68.

Galloway, W.E. 1977. Catahoula Formation of the Texas Coastal Plain: depositional systems, composition, structural development, ground-water flow history, and uranium distribution. University of Texas Bureau of Economic Geology Report Investigation 87.

GEE, C. 2001. The mangrove palm Nypa in the geologic past of the New World. Wetlands Ecology and Management 9, 181-194. DOI 10.1023/A:1011148522181

GRAHAM, A. 1995. diversification of Gulf/Caribbean mangrove communities through Cenozoic time. Biotropica 27(1), 20-27. DOI $10.2307 / 2388899$

GRAHAM, A. 1999. Late Cretaceous and Cenozoic history of North American vegetation. 350 pp. Oxford University Press, Oxford, UK.

GreEnwood, D.R., ARChibald, S.B., MATHEWES, R.W. \& Moss, P.T. 2005. Fossil biotas from the Okanagan Highlands, southern British Columbia and northeastern Washington State: climates and ecosystems across an Eocene landscape. Canadian Journal of Earth Sciences 42(2), 167-185. DOI 10.1139/e04-100

GROTE, P.J. \& DILCHER, D.L. 1989. Investigations of angiosperms from the Eocene of North America: A new genus of Theaceae based on fruit and seed remains. Botanical Gazette 150(2), 190-206. DOI 10.1086/337764

GROTE, P.J. \& DILCHER, D.L. 1992. Fruits and seeds of Tribe Gordonieae (Theaceae) from the Eocene of North America. American Journal of Botany 79(7), 744-753. DOI 10.2307/2444939

HAY, R.L. 1962. Origin and digenetic alternation of the lower parts of the John Day Formation near Mitchell, Oregon, 191-216. In Engle, A.E.J., JAMES, H.L. \& LeONARD, B.F. (eds) Petrologic studies: a volume in honor of A.F. Buddington. Geological Society of America.

HERENDEEN, P.S., CREPET, W.L. \& DiLCHER, D.L. 1992. The fossil history of the Leguminosae: phylogenetic and biogeographic implications, 303-316. In HERENDEEN, P.S. \& DILCHER, D.L. (eds) Advances in Legume Systematics, The Fossil Record. The Royal Botanic Gardens, Kew.

HERENDEEN, P.S. \& DilCHER, D.L. 1990a. Fossil mimisoid legumes from the Eocene and Oligocene of southeastern North
America. Review of Palaeobotany and Palynology 62(3-4), 339-361. DOI 10.1016/0034-6667(90)90094-Y

HERENDEEN, P.S. \& DiLCHER, D.L. 1990b. Diplotropis (Leguminosae, Papilionoideae) from the Middle Eocene of southeastern North America. Systematic Botany 15(4), 526-533. DOI 10.2307/2419152

HERENDEEN, P.S. \& DILCHER, D.L. 1990c. Reproductive and vegetative evidence for the occurrence of Crudia (Leguminosae, Caesalpinioideae) in the Eocene of southeastern North America. Botanical Gazette 151(3), 402-413. DOI 10.1086/337840

HERENDEEN, P.S. \& DilCHER, D.L. 1991. Caesalpinia Subgenus Mezoneuron (Leguminosae, Caesalpinioideae) from the Tertiary of North America. American Journal of Botany 78(1), 1-12. DOI 10.2307/2445223

HERENDEEN, P.S., LES, D.H. \& DilcheR, D.L. 1990. Fossil Ceratophyllum (Ceratophyllaceae) from the Tertiary of North America. American Journal of Botany 77(1), 7-16. DOI $10.2307 / 2444787$

HERnANDEZ-CASTILlo, G.R., STOCKEy, R.A. \& BeARD, G. 2005. Taxodiaceous pollen cones from the early Tertiary of British Columbia, Canada. International Journal of Plant Sciences 166, 339-346. DOI 10.1086/427485

HICKEY, L.J. 1977. Stratigraphy and paleobotany of the Golden Valley Formation (Early Tertiary) of western North Dakota. The Geological Society of America Memoir 150, 1-181.

HILls, L.V. \& BAADSGAARD, H. 1967. Potassium-argon dating of some Lower Tertiary strata in British Columbia. Bulletin of $\mathrm{Ca}$ nadian Petroleum Geology 15, 138-149.

HOLLICK, A. 1932. Descriptions of new species of Tertiary cycads, with a review of those previously recorded. Bulletin of the Torrey Botanical Club 59(4), 169-189. DOI 10.2307/2480541

HoPKINS, D.J. \& JOHNSON, K.R. 1997. First record of cycad leaves from the Eocene Republic flora. Washington Geology 25(4), 37.

Horsfield, B., CURRY, D.J., BOHACS, K.M., CARROLL, A.R., LitTKE, R., MANN, U., RADKE, M., SCHAEFER, R.G., ISAKSEN, G.H., SCHENK, H.J., WITTE, E.G. \& RULLKÖTTER, J. 1994. Organic geochemistry of freshwater and alkaline lacustrine environments, Green River Formation, Wyoming. Organic Geochemistry 22(3-5), 415-440.

DOI 10.1016/0146-6380(94)90117-1

JOHNSON, K.R. 1996. The role of the Republic flora in documenting the floristic evolution of the Northern Hemisphere. Washington Geology 24(2), 41-42.

JOHNSON, K.R., BATEMAN, W., GRAHAM, M., MANCHESTER, S.R. \& HANDley, B. 2002. The Parachute Creek Atlas Project: an overview of the megaflora of the Green River Formation from Colorado and Utah. Geological Society of America Annual Meeting, Denver, October 30, 2002, Paper No. 210-10, Abstract.

JOHNSON, S.Y. 1984a. Evidence for a margin-truncations transcurrent fault (pre-late Eocene) in western Washington. Geology 12(9), 538-541. DOI 10.1130/0091-7613(1984)12<538:EFAMTF>2.0.CO;2

JOHNSON, S.Y. 1984b. Stratigraphy, age, and paleogeography of the Eocene Chuckanut Formation, northwest Washington. $\mathrm{Ca}$ nadian Journal of Earth Sciences 21, 92-106.

JOHNSON, S.Y. 1985. Eocene strike-slip faulting and nonmarine basin formation in Washington, 283-302. In BIDDLE, K.T. \& CHRISTIE-BLICK, N. (eds) Strike-slip deformation, basin formation, and sedimentation. Society of Economic Paleontologists and Mineralogists Special Publication 37. 
JONES, J.H. \& DILCHER, D.L. 1980. Investigations of angiosperms from the Eocene of North America: Rhamnus marginatus (Rhamnaceae) reexamined. American Journal of Botany 67(6), 959-967. DOI 10.2307/2442438

JONES, J.H. \& DILCHER, D.L. 1988. A study of the "Dryophyllum" leaf forms from the Paleogene of southeastern North America. Palaeontographica, Abteilung B 208, 53-80.

KARAFit, S.J., RothWELl, G.W., StOCKey, R A. \& NishidA, H. 2006. Evidence for sympodial vascular architecture in a filicalean fern rhizome: Dickwhitea allenbyensis gen. et sp. nov. (Athyriaceae). International Journal of Plant Sciences 167(3), 721-727. DOI 10.1086/501036

KLymiUK, A.A., STOCKey, R.A. \& RothwelL, G.W. 2009. Evidence for phylogenetic relationships among conifers: the first organismal concept for an extinct species of Pinus. Botany \& Mycology 2009, Abstracts.

KNOWLTON, F.H. 1893. Notes on a few fossil plants from the Fort Union group of Montana, with a description of one new species. United States National Museum Proceedings 16, 33-36.

KVAČEK, Z. 2002. A new Tertiary Ceratozamia (Zamiaceae, Cycadopsida) from the European Oligocene. Flora 197, 303-316.

KVAČEK, Z. \& MANCHESTER, S.R. 1999. Eostangeria Barthel (extinct Cycadales) from the Paleogene of western North America and Europe. International Journal of Plant Sciences 160(3), 621-629. DOI 10.1086/314152

LAKHANPAL, R.N. 1958. The Rujada flora of western central Oregon. University of California Publications in Geological Sciences 35(1), 1-65.

LARSEN, D. \& SMITH, G.A. 1999. Sublacustrine-fan deposition in the Oligocene Creede Formation, Colorado, U.S.A. Journal of Sedimentary Research 69(3), 675-689.

LEOPOLD, E.B. \& MACGINITIE, H.D. 1972. Development and affinities of Tertiary floras in the Rocky Mountains, 147-200. In Graham, A. (ed.) Floristics and Paleofloristics of Asia and Eastern North America. Elsevier, Amsterdam.

LEOPOLD, E.B. \& ClAY-PoOLE, S. 2001. Florissant leaf and pollen floras of Colorado compared: climatic implications, 17-20. In EVANOFF, E., GREGORY-WODZICKI, K.M. \& JOHNSON, K.R. (eds) Fossil flora and stratigraphy of the Florissant Formation, Colorado. Proceedings of the Denver Museum of Nature and Science 4(1).

LitTLE, S.A. \& STOCKEY, R.A. 2003. Vegetative growth of Decodon allenbyensis (Lythraceae) from the Middle Eocene Princeton chert with anatomical comparisons to $D$. verticillatus. International Journal of Plant Sciences 164(3), 453-469. DOI $10.1086 / 367811$

LitTLE, S.A. \& STOCKEY, R.A. 2005. Morphogenesis of the specialized peridermal tissues in Decodon allenbyensis from the Middle Eocene Princeton chert. IAWA (International Association of Wood Anatomists) Bulletin 27, 73-87.

LitTle, S.A., STOCKey, R.A. \& BEARD, G. 2001. Angiosperm fruits and seeds from the Eocene of Vancouver Island. Botany 2001, Abstract.

LitTLE, S.A., StOCKEY, R.A. \& KeAting, R.C. 2004. Duabangalike leaves from the Middle Eocene Princeton chert and comparative leaf histology of Lythraceae sensu lato. American Journal of Botany 91(7), 1126-1139. DOI 10.3732/ajb.91.7.1126

LitTLE, S.A., STOCKey, R.A. \& PENNER, B. 2009. Anatomy and development of fruits of Lauraceae from the Middle Eocene Princeton chert. American Journal of Botany 96(3), 637-651. DOI 10.3732/ajb.0800318
LOTT, T.A., MANCHESTER, S.R. \& DILCHER, D.L. 1998. A unique and complete polemoniaceous plant from the middle Eocene of Utah, USA. Review of Palaeobotany and Palynology 104(1), 39-49. DOI 10.1016/S0034-6667(98)00048-7

MacGinitie, H.D. 1941. Flora of Weaverville Beds of Trinity County, California. Carnegie Institute of Washington Publication 534, 1-167.

MACGinitiE, H.D. 1953. Fossil plants of the Florissant Beds, Colorado. Contributions to Paleontology. Carnegie Institute of Washington Publication 599, 1-197.

MACGINITIE, H.D. 1969. The Eocene Green River flora of northwestern Colorado and northeastern Utah. University of California Publications in Geological Sciences 83, 1-140.

Malchus, M., Hemming, S.R., Olson, P.E. \& Christie-Blick, N. 2002. ${ }^{40} \mathrm{Ar} \mathrm{F}^{39} \mathrm{Ar}$ ages of selected tuffs of the Green River Formation: implications for interbasin and intrabasin correlations. Geological Society of America Annual Meeting, Denver, October 30, 2002, Paper No. 244-19, Abstract.

MANCHESTER, S.R. 1989. Attached reproductive and vegetative remains of the extinct American-European genus Cedrelospermum (Ulmaceae) from the Early Tertiary of Utah and Colorado, USA. American Journal of Botany 76(2), 256-276. DOI $10.2307 / 2444668$

MANCHESTER, S.R. 1992. Flowers, fruits and pollen of Florissantia, an extinct malvalean genus from the Eocene and Oligocene of western North America. American Journal of Botany 79(9), 996-1008. DOI 10.2307/2444909

MANCHESTER, S.R. 1994. Fruits and seeds of the middle Eocene Nut Beds flora, Clarno Formation, Oregon. Palaeontographica Americana 58, 1-205.

MANCHESTER, S.R. 1999. Biogeographical relationships of North American Tertiary floras. Annals of the Missouri Botanical Garden 86(2), 472-522. DOI 10.2307/2666183

MANCHESTER, S.R. 2001. Update on the megafossil flora of Florissant, Colorado, USA, 137-161. In EVANOFF, E., GREGORY-WODZICKI, K.M. \& JOHNSON, K.R. (eds) Fossil flora and stratigraphy of the Florissant Formation, Colorado. Proceedings of the Denver Museum of Nature and Science 4(1).

MANCHESTER, S.R., CHEN, Z., LU, A. \& UEMURA, K. 2009. Eastern Asian endemic seed plant genera and their paleogeographic history thoroughout the Northern Hemisphere. Journal of Systematics and Evolution 47(1), 1-42.

DOI 10.1111/j.1759-6831.2009.00001.x

MANCHESTER, S.R. \& CRANE, P.R. 1983. Attached leaves, inflorescences, and fruits of Fagopsis, an extinct genus of fagaceous affinity from the Oligocene Florissant Flora of Colorado, U.S.A. American Journal of Botany 70(8),1147-1164. DOI 10.2307/2443285

MANCHESTER, S.R. \& CRANE, P.R. 1987. A new genus of Betulaceae from the Oligocene of western North America. Botanical Gazette 148(2), 263-273. DOI 10.1086/337654

MANCHESTER, S.R. \& DILCHER, D.L. 2007. Early Oligocene flora from Huntsville, Texas. 24 $4^{\text {th }}$ Annual Mid-Continent Paleobotanical Colloquium, Southern Methodist University, Dallas, March 16-18, 2007, Abstract.

MANCHESTER, S.R., DILCHER, D.L. \& TIDWELL, W.D. 1986. Interconnected reproductive and vegetative remains of Populus (Salicaceae) from the Middle Eocene Green River Formation, northeastern Utah. American Journal of Botany 73(1), 156-160. DOI 10.2307/2444288

MANCHESTER, S.R., DiLCHER, D.L. \& Wing, S.L. 1998. Attached leaves and fruits of myrtaceous affinity from the Middle Eocene 
of Colorado, USA. Review of Palaeobotany and Palynology 102(3-4), 153-163. DOI 10.1016/S0034-6667(97)00056-0

MANCHESTER, S.R. \& DillhofF, R.M. 2004. Fagus (Fagaceae) fruits, foliage, and pollen from the Middle Eocene of Pacific northwestern North America. Canadian Journal of Botany 82(10), 1509-1517. DOI 10.1139/b04-112

MANChESTER, S.R. \& PIGG, K.B. 2008. The Eocene mystery flower of McAbee, British Columbia. Botany 86(9), 1034-1038. DOI 10.1139/B08-044

MANCHESTER, S.R. \& ZAVADA, M.S. 1987. Lygodium foliage with intact sorophores from the Eocene of Wyoming. Botanical Gazette 148(3), 392-399. DOI 10.1086/337668

MANOS, P.S. \& STANFORD, A.M. 2001. The historical biogeography of Fagaceae: Tracking the Tertiary history of temperate and subtropical forests of the Northern Hemisphere. International Journal of Plant Sciences 162(S6), S77-S93. DOI $10.1086 / 323280$

MANOS, P.S., SOlTIS, P.S., SOlTiS, D.E, MANCHESTER, S.R., OH, SANG-Hu, Bell, D.B., Dilcher, D.L. \& Stone, D.E. 2007. Phylogeny of extant and fossil Juglandaceae inferred from the integration of molecular and morphological data sets. Systematic Biology 56(3), 412-430. DOI 10.1080/10635150701408523

MATHEWES, R.W. \& GREENWOOD, D.R. 2007. Early Eocene Quilcena fossil locality, British Columbia: Paleoclimate and biogeography. Geological Society of America, Abstracts.

MATTHEWS, W.H. 1991. Physiographic evolution of the Canadian Cordillera, 403-418. In GABRIELSE, H. \& YORATH, C.J. (eds) Geology of the Cordilleran orogen in Canada. Geological Survey of Canada, Geology of Canada (4).

MEYER, H.W. 2003. The fossils of Florissant. 258 pp. Smithsonian Books, Washington, DC.

Meyer, H.W. 2004. Plant community dynamics of the EoceneOligocene transition. Geological Society of America Annual Meeting, Denver, November 7-10, 2004, Paper No. 14-11, Abstract.

MEYER, H.W. \& MANCHESTER, S.R. 1997. The Oligocene Bridge Creek flora of the John Day Formation, Oregon. 195 pp. University of California Press, Berkeley.

MILlER, C.N., JR. 1969. Pinus avonensis, a new species of petrified cones from the Oligocene of western Montana. American Journal of Botany 56(9), 972-978. DOI 10.2307/2440918

MILlER, C.N., JR. 1970. Picea diettertiana, a new species of petrified cones from the Oligocene of western Montana. American Journal of Botany 57(5), 579-585. DOI 10.2307/2441056

MILLER, C.N., JR. 1973. Silicified cones and vegetative remains of Pinus from the Eocene of British Columbia. Contributions to the University of Michigan Museum of Paleontology 24, 101-118.

MiLLER, C.N., JR. 1989. A new species of Picea based on silicified seed cones from teh Oligocene of Washington. American Journal of Botany 76(5), 747-754. DOI 10.2307/2444421

MiLler, C.N., JR. 1990. Stems and leaves of Cunninghamiostrobus goedertii from the Oligocene of Washington. American Journal of Botany 77(7), 963-971. DOI $10.2307 / 2444512$

MiLLER, I.M., JOHNSON, K.R. \& ELLIS, B. 2007. A complete cycad plant from the Castle Rock Rainforest: Implications for the evolution and paleo-distribution of American Zamiacaeae. $24^{\text {th }}$ Annual Mid-Continent Paleobotanical Colloquium, Southern Methodist University, Dallas, March 16-18, 2007, Abstract.

Mindall, R.A., StOcKey, R.A. \& BeARD, G. 2006. Anatomically preserved staminate infloescences of Gynoplatananthus oysterbayensis gen. et sp. nov. (Platanaceae) and associated pistillate fructifications from the Eocene of Vancouver Island, British Columbia. International Journal of Plant Sciences 167(3), 591-600. DOI 10.1086/500956

MindAl, R.A., STOCKEY, R.A. \& BEARD, G. 2007. Cascadiacarpa spinosa gen. et sp. nov. (Fagaceae): castaneoid fruits from the Eocene of Vancouver Island, Canada. American Journal of Botany 94(3), 351-361. DOI 10.3732/ajb.94.3.351

Mindall, R.A., Stockey, R.A. \& BeARD, G. 2009. Permineralized Fagus nuts from the Eocene Vancouver Island, Canada. International Journal of Plant Sciences 170 (4), 551-560. DOI 10.1086/596335

Mindall, R.A., StOCKEY, R.A., RothWELl, G.W. \& BEARD, G. 2005. Gleichenia appianensis sp. nov. (Gleicheniaceae): a permineralized rhizome and associated vegetative remains from the Eocene of Vancouver Island, British Columbia. International Journal of Plant Sciences 167(3), 639-647. DOI 10.1086/500997

Moore, B.R., Dilcher, D.L. \& GiBSon, M.A. 2003. Paleoenvironment, depositional setting, and plant fossil diversity found in the Claiborne Formation (Middle Eocene) clay deposits of western Tennessee, 187-198. In Field Trip Guidebook, Joint Meeting South-Central and Southeastern Sections. Geological Society of America (Department of Environment and Conservation, Division of Geology), State of Tennessee, Nashville.

MOORE, B.R. GIBSON, M.A. \& DILCHER, D.L. 2001. An alternative explanation for plant-bearing "varved" sequences from the Wilbanks Clay Pit (Middle Eocene), western Tennessee. Geological Society of America, Southeastern Section, $50^{\text {th }}$ Annual Meeting, April 5-6, 2001, Abstracts.

MustoE, G.E. 2001. Washington's fossil florests. Washington Geology 29(1/2), 10-20.

MustoE, G.E. 2002a. Hydrangea fossils from the early Tertiary Chuckanut Formation. Washington Geology 30(3/4), 17-20.

Mustoe, G.E. 2002b. Eocene Ginkgo leaf fossils from the Pacific Northwest. Canadian Journal of Botany 80(10), 1078-1087. DOI 10.1139/b02-097

MustoE, G.E. 2005. Diatomaceous origin of siliceous shale in Eocene lake beds of central British Columbia. Canadian Journal of Earth Sciences 42(2), 231-241. DOI 10.1139/e04-099

Mustoe, G.E., Dillhoff, R.M. \& DillhofF, T.A. 2007. Geology and paleontology of the early Tertiary Chuckanut Formation, 121-135. In STELLING, P. \& TUCKER, D.S. (eds) Floods, Faults and Fire: Geological Field Trips in Washington State and Southwest British Columbia. Geological Society of America Field Guide 9.

Mustoe, G.E. \& Gannaway, W.L. 1995. Palm fossils from northwest Washington. Washington Geology 23(2), 21-26.

Mustoe, G.E. \& Gannaway, W.L. 1997. Paleogeography and paleontology of the early Tertiary Chuckanut Formation, northwest Washington. Washington Geology 25(3), 3-18.

MYERS, J.A. 2006. The latest Eocene Badger's Nose flora of the Warner Mountains, northeast California: The "in between" flora. Paleobios 26(1), 11-29.

NIESEN, P.L. 1969. Stratigraphic relationships of the Florissant Lake Beds to the Thirtynine Mile volcanic area of central Colorado. 65 pp. Unpublished M.Sc. thesis, New Mexico Institute of Mining and Technology.

OBRADOVICH, J.D., EVANOFF, E. \& LARSON, E.E. 1995. Revised single crystal laser-fusion ${ }^{40} \mathrm{Ar}{ }^{39} \mathrm{Ar}$ ages of Chadronian tuffs in the White River Formation of Wyoming. Geological Society of America Abstracts Programs 27(3), A77. 
PABST, M.B. 1968. The flora of the Chuckanut Formation of northwestern Washington, the Equisetales, Filicales, and Coniferales. University of California Publications of Geological Sciences 227, 166-169.

PIGG, K.B. \& DEVORE, M.L. 2010. Floristic composition and transitions of Late Paleocene to Early Eocene floras in western North America. Bulletin of Geosciences 85(1), 75-94. DOI 10.3140/bull.geosci.1136

PIGG, K.B. \& DEVoRE, M.L. 2007. East meets West: the contrasting contributions of David L. Dilcher and Jack A. Wolfe to Eocene systematic paleobotany in North America. In JARZEN, D.M., RETALLACK, G., JARZEN, S. \& MANCHESTER, S.R. (eds) Advances in Mesozoic and Cenozoic Paleobotany. Courier Forschungsinstitut Senckenberg 258, 85-94.

PIGG, K.B., DeVore, M.L., DilcheR, D.L. \& FreILE, D. 2001a. Fagaceous infructescences from the Oligocene Catahoula Formation of Texas. Botany 2001, Abstracts, 68.

PigG, K.B., Dillhoff, R.M., DeVore, M.L. \& WeHR, W.C. 2007. New diversity among the Trochodendraceae from the Early/Middle Eocene Okanogan Highlands of British Columbia, Canada and northeastern Washington State, United States. International Journal of Plant Sciences 168(4), 521-532. DOI 10.1086/512104

PigG, K.B., MANCheSter, S.R. \& Wehr, W.C. 2003. Corylus, Carpinus and Palaeocarpinus (Betulaceae) from the Middle Eocene Klondike Mountain and Allenby Formations of northwestern North America. International Journal of Plant Sciences 164(5), 807-822. DOI 10.1086/376816

PigG, K.B. \& Stockey, R.A. 1996. The significance of the Princeton chert permineralized flora to the Middle Eocene upland biota of the Okanogan Highlands. Washington Geology 24(2), 32-36.

PIGG, K.B. \& WEHR, W.C. 2002. Tertiary flowers, fruits and seeds of Washington State and adjacent areas. Part III. Washington Geology 30(3/4), 3-16.

PIGG, K.B., WEHR, W.C. \& ICKERT-BOND, S.M. 2001b. Trochodendron and Nordenskioldia (Trochodendraceae) from the Middle Eocene of Washington State, U.S.A. International Journal of Plant Sciences 162(5), 1187-1198. DOI 10.1086/321927

POTBURY, S.S. 1935. The La Porte flora of Plumas County, California, 29-81. In SANBORN, E.L., POTBURY, S.S. \& MACGINITIE, H.D. (eds) Carnegie Institution of Washington Contributions to Paleontology 465.

POTTER, F. \& DILCHER, D.L. 1980. Biostratigraphic analysis of Middle Eocene floras of western Kentucky and Tennessee. Chapter 8, 211-225. In Dilcher, D.L. \& TAYLOR, T.N. (eds) Biostratigraphy of Fossil Plants: Successional and Paleoecological Analysis. Dowden, Hutchinson \& Ross, Stroudsburg, Pennsylvania.

RADTKE, M.G., PIGG, K.B. \& WEHR, W.C. 2005. Fossil Corylopsis and Fothergilla leaves (Hamamelidaceae) from the Lower Eocene flora of Republic, Washington, U.S.A., and their evolutionary and biogeographic significance. International Journal of Plant Science 166(2), 347-356. DOI 10.1086/427483

RAMíREZ-PeÑA, D.L., HeRnANDEZ-CASTILlo, G.R. \& STOCKEY, R.A. 2009. A new ovulate cone (Cupressaceae: Sequoioideae) from the Appian Way (Eocene), British Columbia, Canada. Botany 2009, Abstracts.

RANKIN, B.D., StOckeY, R.A. \& BEARD, G. 2008. Fruits of Icacinaceae from the Eocene Appian Way locality. International Journal of Plant Sciences 169(2), 305-314. DOI $10.1086 / 523876$

RATTE, J.C. \& STEVEN, T.A. 1967. Ash flows and related volcanic rocks associated with the Creede Caldera, San Juan Mountains, Colorado. United States Geological Survey Professional Paper 524- $\mathrm{H}, \mathrm{H} 1-\mathrm{H} 58$.

REID, E.M. \& CHANDLER, M.E.J. 1933. The London Clay flora. 561 pp. British Museum of Natural History, London.

REINECK, H.E. \& SINGH, I.B. 1980. Depositional Sedimentary Environments. 549 pp. Springer-Verlag, New York.

RoBINSON, P.T., BREM, G.F. \& MCKEE, E.H. 1984. John Day Formation of Oregon: A distal record of early Cascade volcanism. Geology 12(4), 229-232.

DOI 10.1130/0091-7613(1984)12<229:JDFOOA >2.0.CO;2

Robinson, P.T., WALKeR, G.W. \& MCKeE, E.H. 1990. Eocene(?), Oligocene and lower Miocene rocks of the Blue Mountains region, 29-61. In WALKER, G.W. (ed.) Geology of the Blue Mountains region. United States Geological Survey Professional Paper 1437.

ROBISON, C.R. \& PERSON, C.P. 1973. A silicified semiaquatic dicotyledon from the Eocene Allenby Formation of British Columbia. Canadian Journal of Botany 51(7), 1373-1377. DOI 10.1139/b73-172

ROEHLER, H.W. 1993. Eocene climates, depositional environments, and geography, greater Green River basin, Wyoming, Utah, and Colorado. United States Geological Survey Professional Paper 1506-F, 1-74.

ROTH, J. \& DILCHER, D.L. 1979. Investigations of angiosperms from the Eocene of North America: stipulate leaves of the Rubiaceae. American Journal of Botany 66(10), 1194-1207. DOI $10.2307 / 2442218$

ROTHWELL, G.W. \& BASINGER, J.F. 1979. Metasequoia milleri n. sp., anatomically preserved pollen cones from the middle Eocene (Allenby Formation) of British Columbia. Canadian Journal of Botany 57(8), 958-970. DOI 10.1139/b79-118

ROTHWELL, G.W. \& STOCKEY, R.A. 1989. Onoclea sensibilis in the Paleocene of North America, a dramatic example of structural and ecological stasis. Review of Palaeobotany and Palynology 70(1-2), 113-124.

SANBORN, E.I. 1935. The Comstock flora of west central Oregon, 1-28. In SANBORN, E.L., POTBURY, S.S. \& MACGINITIE, H.D. (eds) Carnegie Institution of Washington Contributions to Paleontology 465.

SANTIAGO-VAlEntin, E. \& OlmSteAd, R.G. 2004. Historical biogeography of Caribbean plants: introduction to current knowledge and possibilities from a phylogenetic perspective. Taxon 53(2), 299-319. DOI 10.2307/4135610

SCHORN, H.E. 1998. Holodiscus lisii (Rosaceae): a new species of ocean spray from the late Eocene Florissant Formation, Colorado, USA. PaleoBios 18, 21-24.

SCHORN, H.E. \& WEHR, W.C. 1996. The conifer flora from the Eocene uplands at Republic, Washington. Washington Geology 24(2), 22-24.

SChweItZer, C.E., Feldman, R.M., FARn, J., Hessin, W.A., Hetrick, S.W., NYBORG, T.G. \& Ross, R.L.M. 2003. Cretaceous and Eocene decapod crustaceans from southern Vancouver Island, British Columbia, Canada. 66 pp. National Research Council, Ottawa.

SMITH, G.A., MANCHESTER, S.R., ASHWILL, M., MCINTOSH, W.C. \& CONREY, R.M. 1998. Late Eocene-early Oligocene tectonism, volcanism, and floristic change near Gray Butte, central Oregon. Geological Society of America Bulletin 100, 759-778.

DOI 10.1130/0016-7606(1998)110<0759:LEEOTV>2.3.CO;2

SMITH, H V. 1938. Some new and interesting Late Tertiary plants 
from Sucker Creek, Idaho-Oregon boundary. Bulletin of the Torrey Botanical Club 65, 557-564. DOI 10.2307/2480794

SMITH, R., GREENWOOD, D.R. \& BASINGER, J.F. 2007. Forest $d y$ namics during Eocene greenhouse conditions: assessing ecosystem resilience and diversity in the megafloral record of the Okanagan Highlands, British Columbia. Geological Society of America Annual Meeting, Denver, 28-31 October 2007, Paper No. 112-4, Abstract.

SMITH, S.Y. \& STOCKEY, R.A. 2007a. Establishing a fossil record for the perianthless Piperales: Saururus tuckerae sp. nov. (Saururaceae) from the Middle Eocene Princeton chert. American Journal of Botany 94(10), 1642-1657. DOI 10.3732/ajb.94.10.1642

SMith, S.Y. \& STOCKEY, R.A. 2007b. Pollen morphology and ultrastructure of Saururaceae. Grana 46, 250-267. DOI 10.1080/00173130701780427

Smith, S.Y., Stockey, R.A., Nishida, H. \& Rothwell, G.W. 2006. Trawetsia princetonensis gen. et sp. nov. (Blechnaceae): a permineralized fern from the Middle Eocene Princeton Chert. International Journal of Plant Sciences 167(3), 711-719. DOI 10.1086/501034

SteEnBock, C.M., STOCKeY, R.A., BEARD, G. \& TOMESCU, A. 2009. Anatomically preserved fossil moss gametophytes from the Eocene of Vancouver Island, British Columbia, Canada. Botany \& Mycology 2009, Snowbird, Utah, July 25-27, Abstract.

STOCKEY, R.A. 1987. A permineralized flower from the Middle Eocene of British Columbia. American Journal of Botany 74(12), 1878-1887. DOI 10.2307/2443970

STOCKEY, R.A. 2001. Princeton chert, 359-362. In BRIGGS, D.H. (ed.) Palaeobiology II. Blackwell Science.

StOcKey, R.A., NishidA, H. \& Rothwell, G.W. 1999. Permineralized ferns from the Middle Eocene Princeton chert. I. Makotopteris princetonensis gen. et sp. nov. (Athyriaceae). International Journal of Plant Sciences 160(5), 1047-1055.

Stockey, R.A. \& PigG, K.B. 1991. Flowers and fruits of Princetonia allenbyensis (Magnoliopsida family indet.) from the Middle Eocene Princeton chert of British Columbia. Review of Palaeobotany and Palynology 70, 163-172. DOI 10.1016/0034-6667(91)90084-G

STOCKEY, R.A. \& PIGG, K.B. 1994. Vegetative growth of Eorhiza arnoldii Robison and Person from the Middle Eocene Princeton chert locality of British Columbia. International Journal of Plant Sciences 155(5), 606-616. DOI 10.1086/297199

SWEET, A. 2005. Applied research report on four Tertiary samples from Appian Way plant locality, east coast of Vancouver Island near Campbell River. Geological Survey of Canada Paleontological Report 02-ARS-2005. Geological Survey of Canada, Calgary, Alberta.

SwISHER, C.C. \& PROTHERO, D.R. 1990. Single crystal ${ }^{40} \mathrm{Ar} /{ }^{39} \mathrm{Ar}$ dating of the Eocene-Oligocene transition in North America. Science 249(4970), 760-762. DOI 10.1126/science.249.4970.760

TIFFNEY, B.H. 1999. Early Eocene vertebrates and plants from the Fisher/Sullivan Site (Nanjemoy Formation) Stafford County, Virginia. 159 pp. Virginia Division of Mineral Resources Publication 152, Commonwealth of Virginia, Department of Mines, Minerals and Energy, Charlottesville, Virginia.

TIFFNEY, B.H. \& MANCHESTER, S.R. 2001. The use of geological and paleontological evidence in evaluating plant phylogeographic hypotheses in the Northern Hemisphere Tertiary. International Journal of Plant Sciences 162(S6), S3-S17. DOI 10.1086/323880

TRIVETT, M.L., STOCKEY, R.A., ROTHWELL, G.W. \& BEARD, G.
2006. Paralygodium vancouverensis sp. nov. (Schizaeaceae): additional evidence for filicalean diversity in the Paleogene of North America. International Journal of Plant Sciences 167(3), 675-681. DOI 10.1086/500986

TUTA, J.A. 1967. Fossil palms. Principes 11, 54-71.

WEHR, W.C. 1995. Early Tertiary flowers, fruits and seeds of Washington State and adjacent areas. Washington Geology 23(3), 3-16.

WEHR, W.C. \& HOPKINS, D.Q. 1994. The Eocene orchards and gardens of Republic, Washington. Washington Geology 22(3), $27-34$.

WeHR, W.C. \& MANCHESTER, S.R. 1996. Paleobotanical significance of Eocene flowers, fruits, and seeds from Republic, Washington. Washington Geology 24(2), 25-27.

WHEELER, E.A. \& MANCHESTER, S.R. 2002. Woods of the Eocene Nut Beds Flora, Clarno Formation, Oregon, USA. IAWA Journal Supplement 3. International Association of Wood Anatomists, Nationaal Herbarium Nederland, The Netherlands.

WING, S.L. 1987. Eocene and Oligocene flora and vegetation of the Rocky Mountains. Annals of the Missouri Botanical Garden 74, 748-784. DOI 10.2307/2399449

WoBUS, R.A. \& EPIS, R.C. 1978. Geologic map of the Florissant 15-minute quadrangle, Park and Teller Counties, Colorado. Washington, D.C. United States Government Printing Office U.S. Geological Survey Miscellaneous Investigations Series Map I-1044, 1 sheet, scale $1: 62,500$.

WOLFE, J.A. 1968. Paleogene biostratigraphy of nonmarine rocks in King County, Washington. United States Geological Survey Professional Paper 571, 1-33.

WOLFE, J.A. 1977. Paleocene floras of the Gulf of Alaska region. United States Geological Survey Professional Paper 997, 1-108.

WOLFE, J.A. 1978. A paleobotanical interpretation of Tertiary climates in the Northern Hemisphere. American Scientist 66(6), 694-703.

WOLFE, J.A. 1987. An overview of the origins of the modern vegetation and flora of the northern Rocky Mountains. Annals of the Missouri Botanical Garden 74(4), 785-803. DOI 10.2307/2399450

WOLFE, J.A. \& SCHORN, H.E. 1989. Paleoecologic, paleoclimatic and evolutionary significance of the Oligocene Creede flora, Colorado. Paleobiology 15(2), 180-198.

WOLFE, J.A. \& SCHORN, H.E. 1990. Taxonomic revision of the Spermatopsida of the Oligocene Creede flora, southern Colorado. United States Geological Survey Bulletin 1923, 1-40.

WOLFE, J.A. \& TANAI, T. 1987. Systematics, phylogeny, and distribution of Acer (maples) in the Cenozoic of western North America. Journal of the Faculty of Science, Hokkaido University, Series IV 22, 1-246.

WolfE, J.A. \& WeHR, W. 1987. Middle Eocene dicotyledonous plants from Republic, northeastern Washington. United States Geological Survey Bulletin 1597, 1-25.

YANG, J., WANG, Y-F., SPICER, R.A., MOSBRUGGER, V., LI, C.-S. \& SUN, Q.-G. 2007. Climatic reconstruction at the Miocene Shanwang basin, China, using leaf margin analysis, CLAMP, coexistence approach, and overlapping distribution analysis. American Journal of Botany 94(4), 599-608. DOI 10.3732/ajb.94.4.599

ZAVADA, M.S. \& CREPET, W.L. 1981. Investigations of angiosperms from the Middle Eocene of North America: Flowers of the Celtidoideae. American Journal of Botany 68(7), 924-933. DOI $10.2307 / 2443223$

ZONA, S. 1990. A monograph of Sabal (Arecaceae: Coryphoideae). Aliso 12, 583-666. 